\title{
Catalytic Asymmetric Intramolecular $\alpha$-Alkylation of Aldehydes
}

\section{Supporting Information}

\author{
Nicola Vignola and Benjamin List* \\ Max-Planck-Institut für Kohlenforschung, D-45470 Mülheim an der Ruhr, Germany, \\ list@mpi muelheim.mpg.de
}

Substrate Syntheses:
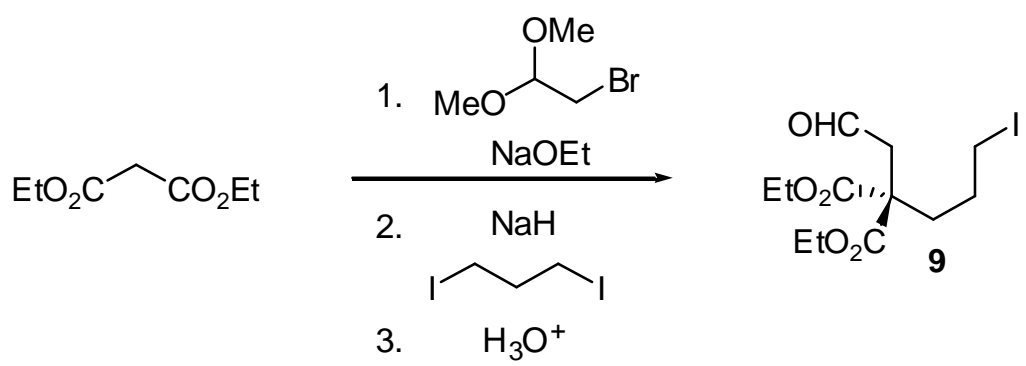

Acetal A. Sodium (100 mmol, $2.3 \mathrm{~g})$ was dissolved in dry ethanol $(70 \mathrm{~mL})$ and the solution was heated to $80^{\circ} \mathrm{C}$. Diethylmalonate $(90 \mathrm{mmol}, 13.6 \mathrm{~mL})$ was added and the mixture was stirred for further $30 \mathrm{~min}$. After the addition of 2-bromo-1,1-dimethoxyethane $(120 \mathrm{mmol}, 14 \mathrm{~mL})$ the mixture was refluxed for $36 \mathrm{~h}$. The mixture was allowed to cool down to $\mathrm{rt}$ and the solvent was removed in vacuo. Dichloromethane and water were added and the aqueous phase was extracted with dichloromethane. The combined organic extracts were washed with brine, dried $\left(\mathrm{MgSO}_{4}\right)$, filtered, and concentrated. The residue was purified on a silica gel column (5\% ethyl acetate/hexane) to give acetal $\mathbf{A}$ (14.2 g, $57.6 \mathrm{mmol}, 64 \%)$.

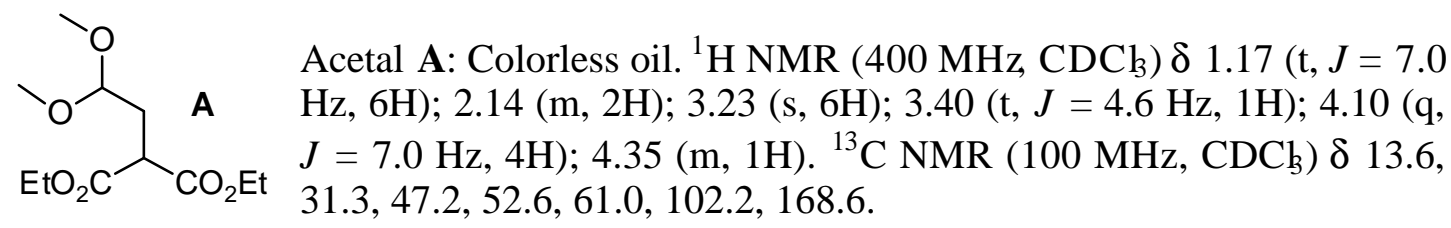

Acetal B. To acetal A $(3 \mathrm{~g}, 12 \mathrm{mmol})$ in dry THF $(60 \mathrm{~mL})$ was added sodium hydride $(0.32 \mathrm{~g}, 13.2 \mathrm{mmol})$ at $0^{\circ} \mathrm{C}$ and the mixture was allowed to warm to $\mathrm{rt}$ until gas evolution ceased. After addition of 1,3-diiodo-propane $(24 \mathrm{mmol}, 2.7 \mathrm{~mL})$ the mixture was refluxed for $24 \mathrm{~h}$. Additional 1,3-diiodo-propane $(1 \mathrm{~mL})$ was added and the mixture was refluxed for further $12 \mathrm{~h}$. After the mixture was allowed to cool down to rt dichloromethane and water were added and the aqueous phase was extracted with dichloromethane. The combined organic extracts were washed with brine, dried $\left(\mathrm{MgSO}_{4}\right)$, filtered, and concentrated. The residue was purified on a silica gel column (5\% ethyl acetate/hexane) to give acetal $\mathbf{B}(3.6 \mathrm{~g}, 72 \%)$. 


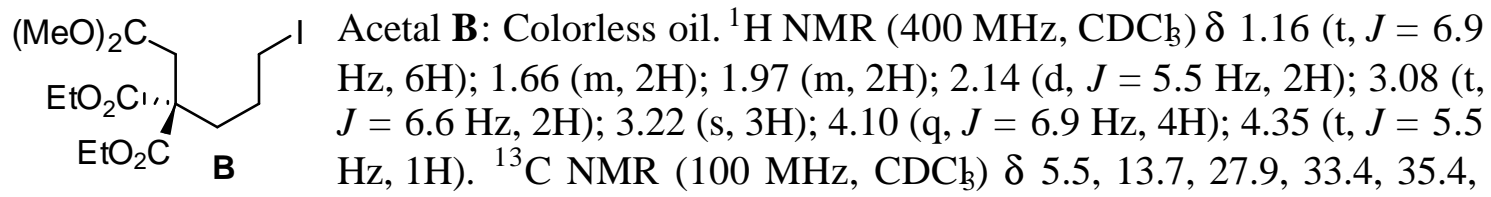
$53.1,54.4,61.0,101.5,171.4$.

Aldehyde 9. To acetal $\mathbf{B}(2 \mathrm{~g}, 4.8 \mathrm{mmol})$ in acetone $(7 \mathrm{~mL})$ and water $(7 \mathrm{~mL})$ was added $p$-toluene-sulfonic acid $(0.72 \mathrm{mmol}, 0.12 \mathrm{~g})$ and the mixture was refluxed for $2 \mathrm{~h}$ After the mixture was allowed to cool down to rt dichloromethane and water were added and the aqueous phase was extracted with dichloromethane. The combined organic extracts were washed with saturated aqueous $\mathrm{NaHCO}_{3}$-solution, dried $\left(\mathrm{MgSO}_{4}\right)$, filtered, and concentrated. The residue was purified on a silica gel column (5\% ethyl acetate/hexane) to give aldehyde $9(1.4 \mathrm{~g}, 81 \%)$.
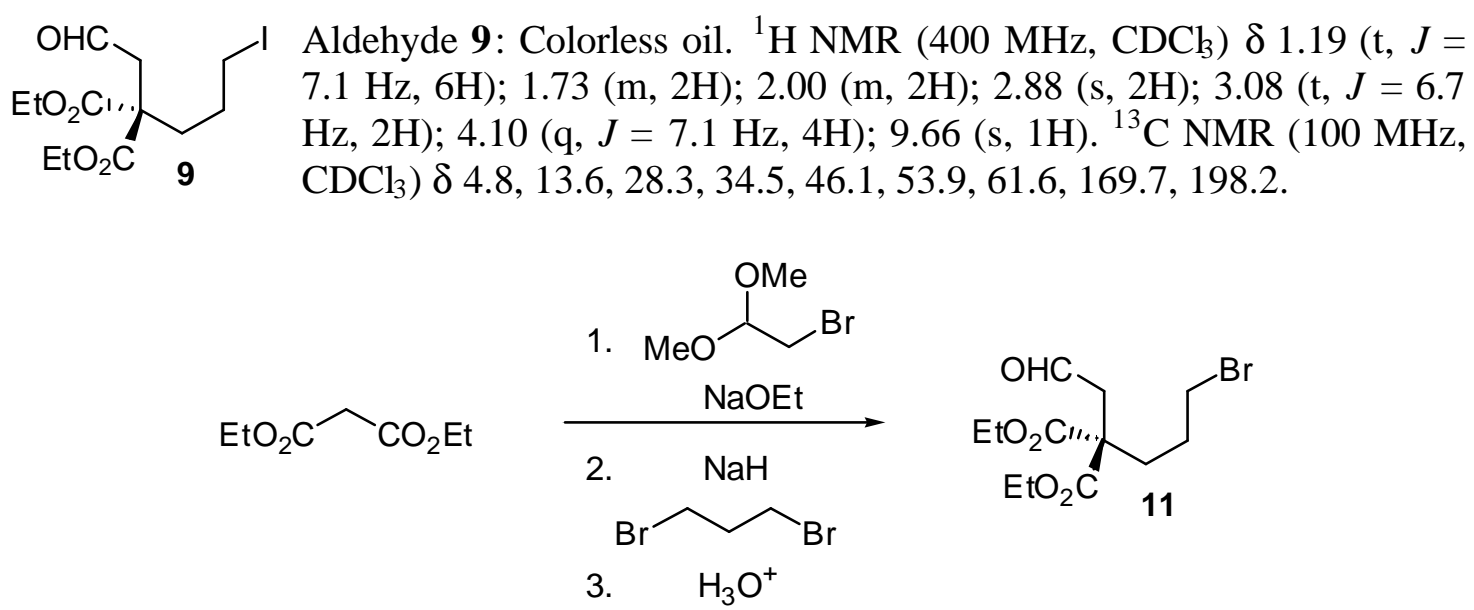

Acetal C. To acetal A (3 g, $12 \mathrm{mmol})$ in dry THF $(60 \mathrm{~mL})$ was added sodium hydride $(0.32 \mathrm{~g}, 13.2 \mathrm{mmol})$ at $0^{\circ} \mathrm{C}$ and the mixture was allowed to warm to room temperature until gas evolution ceased. After addition of 1,3-diiodo-propane ( $24 \mathrm{mmol}, 2.7 \mathrm{~mL})$ the mixture was refluxed for $24 \mathrm{~h}$. Additional 1,3-diiodo-propane $(1 \mathrm{~mL})$ was added and the mixture was refluxed for further $12 \mathrm{~h}$. After the mixture was allowed to cool down to $\mathrm{rt}$ dichloromethane and water were added and the aqueous phase was extracted with dichloromethane. The combined organic extracts were washed with brine, dried $\left(\mathrm{MgSO}_{4}\right)$, filtered, and concentrated. The residue was purified on a silica gel column $(5 \%$ ethyl acetate/hexane) to give acetal $\mathbf{C}(3.4 \mathrm{~g}, 77 \%)$.

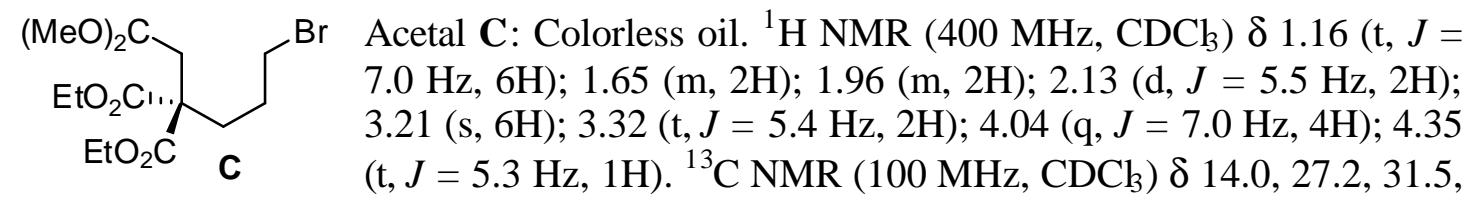
33.1, 36.2, 53.2, 54.1, 61.3, 101.9, 171.8. 
Aldehyde 11. To acetal $\mathbf{C}(3 \mathrm{~g}, 8.1 \mathrm{mmol})$ in acetone $(12 \mathrm{~mL})$ and water $(12 \mathrm{~mL})$ was added $p$-toluene-sulfonic acid $(1.2 \mathrm{mmol}, 0.2 \mathrm{~g})$ and the mixture was refluxed for $2 \mathrm{~h}$. After the mixture was allowed to cool down to rt dichloromethane and water were added and the aqueous phase was extracted with dichloromethane. The combined organic extracts were washed with saturated aqueous $\mathrm{NaHCO}_{3}$-solution, dried $\left(\mathrm{MgSO}_{4}\right)$, filtered, and concentrated. The residue was purified on a silica gel column (5\% ethyl acetate/hexane) to give aldehyde $\mathbf{1 1}(2.3 \mathrm{~g}, 88 \%)$.
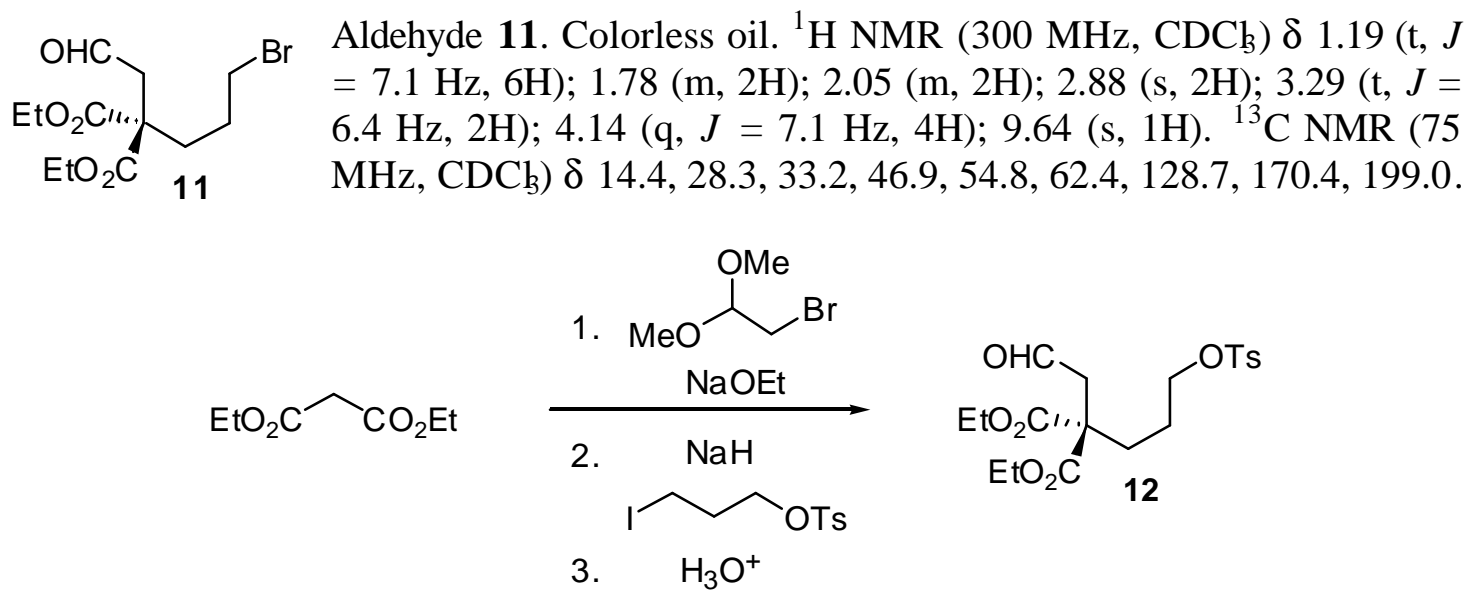

Acetal D. To acetal A $(1.2 \mathrm{~g}, 5 \mathrm{mmol})$ in dry THF $(40 \mathrm{~mL})$ was added sodium hydride $(0.13 \mathrm{~g}, 5.5 \mathrm{mmol})$ at $0^{\circ} \mathrm{C}$ and the mixture was allowed to warm to room temperature until gas evolution ceased. After addition of $p$-toluenesulfonic acid 3-iodo-propyl ester $(7.9 \mathrm{mmol}, 2.7 \mathrm{~g})$ the mixture was refluxed for $36 \mathrm{~h}$. After the mixture was allowed to cool down to rt dichloromethane and water were added and the aqueous phase was extracted with dichloromethane. The combined organic extracts were washed with brine, dried $\left(\mathrm{MgSO}_{4}\right)$, filtered, and concentrated. The residue was purified on a silica gel column (5\% ethyl acetate/hexane) to give acetal D (1.6 g, 69\%).

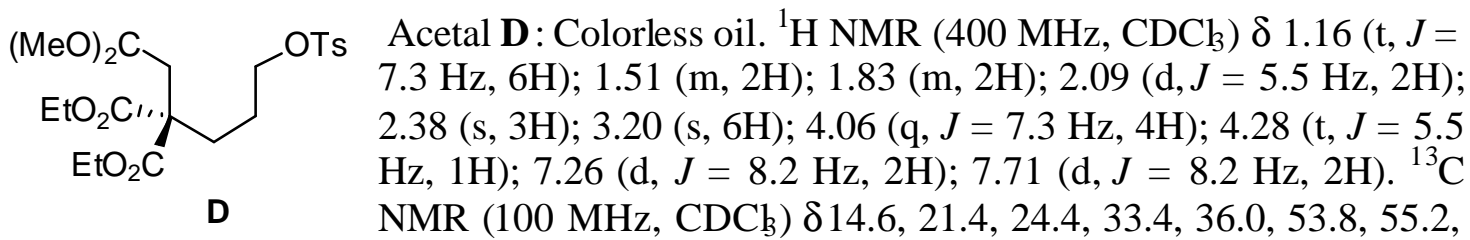

61.6, 70.5, 102.3, 128.3, 130.2, 133.4, 145.2, 171.2.

Aldehyde 12. To acetal $\mathbf{D}(1.5 \mathrm{~g}, 3.3 \mathrm{mmol})$ in acetone $(5 \mathrm{~mL})$ and water $(5 \mathrm{~mL})$ was added $p$-toluene-sulfonic acid $(0.72 \mathrm{mmol}, 0.12 \mathrm{~g})$ the mixture was refluxed for $2 \mathrm{~h}$. After the mixture was allowed to cool down to rt dichloromethane and water were added and the aqueous phase was extracted with dichloromethane. The combined organic extracts were washed with saturated aqueous $\mathrm{NaHCO}_{3}$-solution, dried $\left(\mathrm{MgSO}_{4}\right)$, filtered, and concentrated. The residue was purified on a silica gel column (5\% ethyl acetate/hexane) to give aldehyde $12(0.9 \mathrm{~g}, 66 \%)$. 


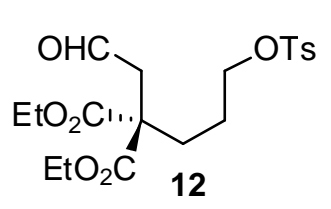

Aldehyde 12: Colorless oil. ${ }^{1} \mathrm{H}$ NMR $(400 \mathrm{MHz}, \mathrm{CDCb}) \delta 1.16(\mathrm{t}, J$ $=7.1 \mathrm{~Hz}, 6 \mathrm{H}) ; 1.57(\mathrm{~m}, 2 \mathrm{H}) ; 1.90(\mathrm{~m}, 2 \mathrm{H}) ; 2.09(\mathrm{~s}, 3 \mathrm{H}) ; 2.83(\mathrm{~s}$, $2 \mathrm{H}) ; 3.93(\mathrm{t}, J=6.3 \mathrm{~Hz}, 2 \mathrm{H}) ; 4.11(\mathrm{q}, J=7.1 \mathrm{~Hz}, 4 \mathrm{H}) ; 7.23(\mathrm{~d}, J=$ $8.3 \mathrm{~Hz}, 2 \mathrm{H}) ; 7.69(\mathrm{~d}, J=8.3 \mathrm{~Hz}, 2 \mathrm{H}) ; 9.60(\mathrm{~s}, 1 \mathrm{H}) .{ }^{13} \mathrm{C}$ NMR $(100$ $\left.\mathrm{MHz}, \mathrm{CDCb}_{3}\right) \delta 13.7,19.4,24.0,29.7,45.9,53.9,61.5,69.5,127.7$, $129.5,132.5,144.5,169.6,198.4$.
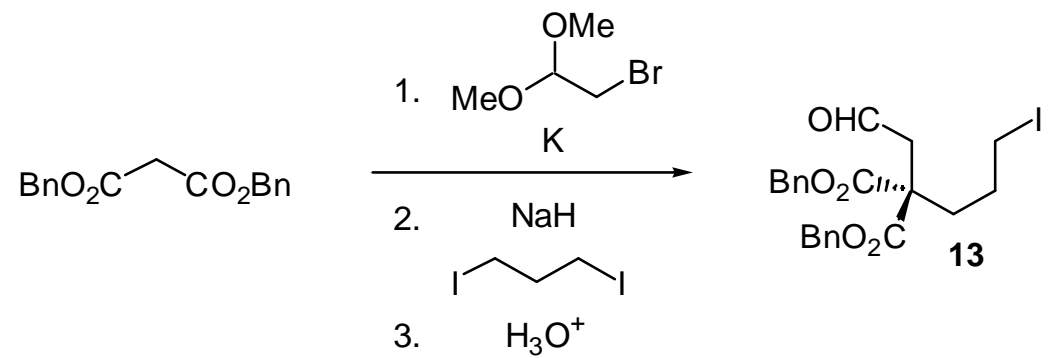

Acetal E. Dibenzylmalonate (30 mmol, $8.5 \mathrm{~g})$ was dissolved in dry toluene $(70 \mathrm{~mL})$ and potassium $(30 \mathrm{mmol}, 1.2 \mathrm{~g})$ was added at $0^{\circ} \mathrm{C}$. The mixture was stirred for $3 \mathrm{~h}$ at $\mathrm{rt}$ and then refluxed for $2 \mathrm{~h}$. The mixture was cooled to $\mathrm{rt}$ and 2-bromo-1,1-dimethoxy-ethane $(60 \mathrm{mmol}, 7 \mathrm{~mL}$ ) was added before the mixture was refluxed for $36 \mathrm{~h}$. The mixture was allowed to cool down to rt. Dichloromethane and water were added and the aqueous phase was extracted with dichloromethane. The combined organic extracts were washed with brine, dried $\left(\mathrm{MgSO}_{4}\right)$, filtered, and concentrated. The residue was purified on a silica gel column (5\% ethyl acetate/hexane) to give acetal E (5.7 g, $15.3 \mathrm{mmol}, 51 \%)$.

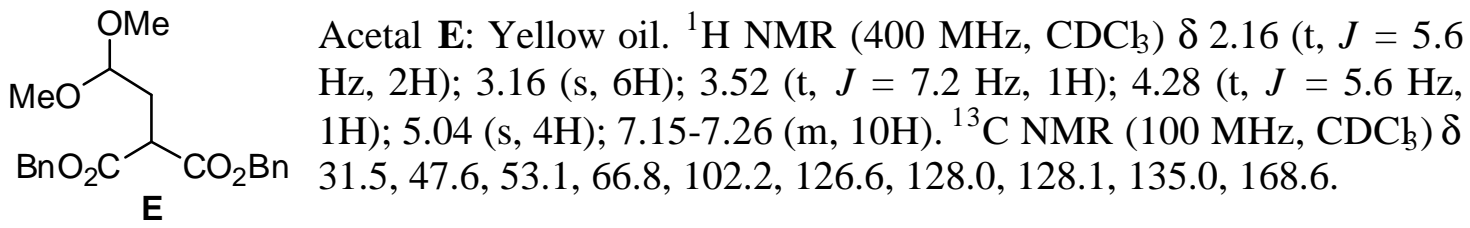

Acetal F. To acetal $\mathbf{E}(12 \mathrm{mmol}, 4.4 \mathrm{~g})$ in dry THF $(60 \mathrm{~mL})$ was added sodium hydride $(0.32 \mathrm{~g}, 13.2 \mathrm{mmol})$ at $0^{\circ} \mathrm{C}$ and the mixture was allowed to warm to room temperature until gas evolution ceased. After addition of 1,3-diiodo-propane $(24 \mathrm{mmol}, 2.7 \mathrm{~mL})$ the mixture was refluxed for $24 \mathrm{~h}$. Additional 1,3-diiodo-propane $(1 \mathrm{~mL})$ was added and the mixture was refluxed for further $12 \mathrm{~h}$. After the mixture was allowed to cool down to $\mathrm{rt}$ dichloromethane and water were added and the aqueous phase was extracted with dichloromethane. The combined organic extracts were washed with brine, dried $\left(\mathrm{MgSO}_{4}\right)$, filtered, and concentrated. The residue was purified on a silica gel column $(5 \%$ ethyl acetate/hexane) to give acetal F (3.9 g, $7.2 \mathrm{mmol}, 60 \%)$.

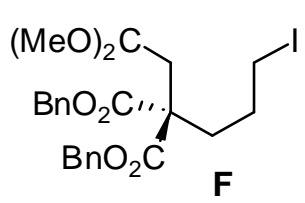

170.5 .
Acetal F: Yellow oil. ${ }^{1} \mathrm{H}$ NMR $(400 \mathrm{MHz}, \mathrm{CDCb}) \delta 1.63(\mathrm{~m}, 2 \mathrm{H})$; $2.06(\mathrm{~m}, 2 \mathrm{H}) ; 2.25(\mathrm{~d}, J=5.3 \mathrm{~Hz}, 2 \mathrm{H}) ; 3.03(\mathrm{t}, J=6.7 \mathrm{~Hz}, 2 \mathrm{H}) ; 3.26$ $(\mathrm{s}, 6 \mathrm{H}) ; 4.39(\mathrm{t}, J=5.5 \mathrm{~Hz}, 1 \mathrm{H}) ; 5.04(\mathrm{~d}, J=12.1 \mathrm{~Hz}, 2 \mathrm{H}) ; 5.09(\mathrm{~d}, J$ $=12.1 \mathrm{~Hz}, 2 \mathrm{H}) ; 7.29(\mathrm{~m}, 10 \mathrm{H}) .{ }^{13} \mathrm{C} \mathrm{NMR}\left(100 \mathrm{MHz}, \mathrm{CDCl}_{3}\right) \delta 5.5$, 28.2, 33.8, 37.6, 53.6, 55.4, 67.1, 101.8, 127.7, 128.0, 128.2, 135.4, 
Aldehyde 13. To acetal $\mathbf{F}(2 \mathrm{~g}, 3.7 \mathrm{mmol})$ in acetone $(5 \mathrm{~mL})$ and water $(5 \mathrm{~mL})$ was added $p$-toluene-sulfonic acid $(0.56 \mathrm{mmol}, 0.1 \mathrm{~g})$ and the mixture was refluxed for $2 \mathrm{~h}$. After the mixture was allowed to cool down to $\mathrm{rt}$ dichloromethane and water were added and the aqueous phase was extracted with dichloromethane. The combined organic extracts were washed with saturated aqueous $\mathrm{NaHCO}_{3}$-solution, dried $\left(\mathrm{MgSO}_{4}\right)$, filtered, and concentrated. The residue was purified on a silica gel column (5\% ethyl acetate/hexane) to give aldehyde $\mathbf{1 3}$ (1.2 g, $2.4 \mathrm{mmol}, 65 \%)$.
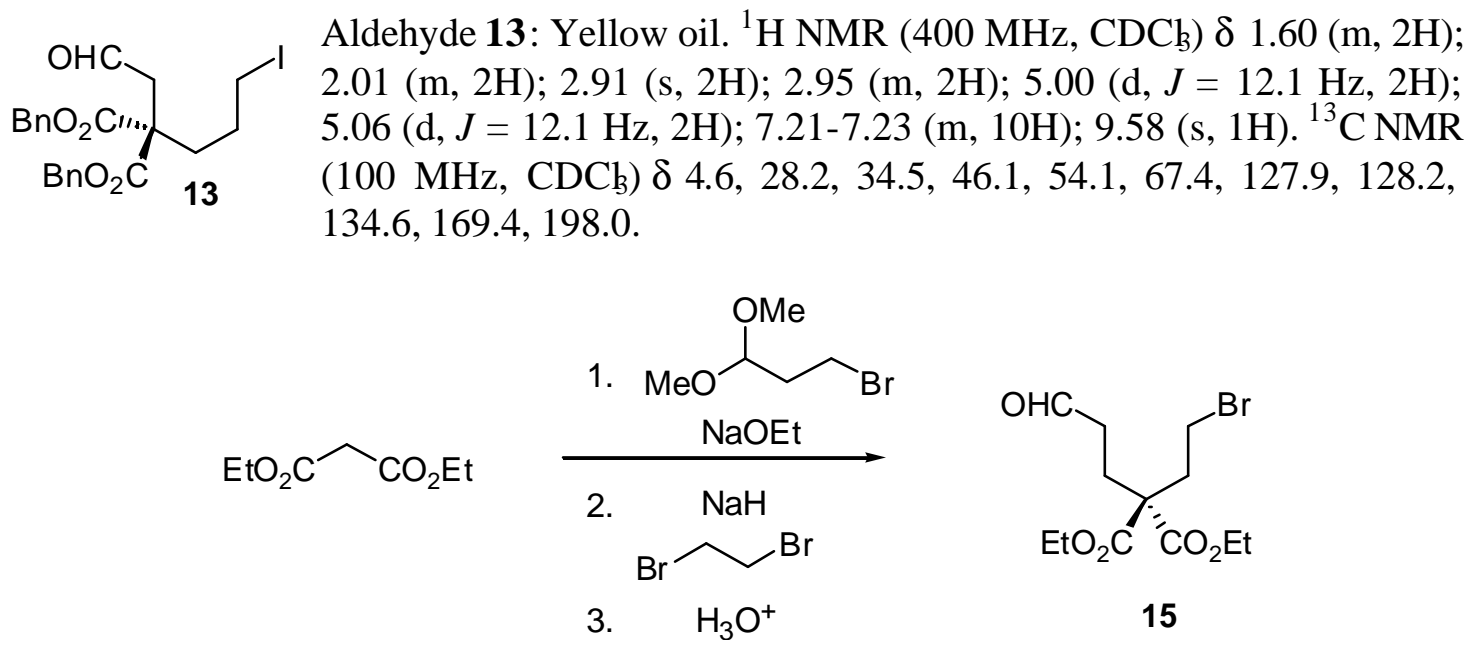

Acetal G. Sodium (46 mmol, $1.1 \mathrm{~g})$ was dissolved in dry ethanol $(35 \mathrm{~mL})$ and the solution was heated to $80^{\circ} \mathrm{C}$. Diethylmalonate $(45 \mathrm{mmol}, 6.8 \mathrm{~mL})$ was added and the mixture was stirred for further $30 \mathrm{~min}$. After the addition of 3-bromo-1,1-dimethoxypropane ( $49 \mathrm{mmol}, 9 \mathrm{~g}$ ) the mixture was refluxed for $36 \mathrm{~h}$. The mixture was allowed to cool down to $\mathrm{rt}$ and the solvent was removed in vacuo. Dichloromethane and water were added and the aqueous phase was extracted with dichloromethane. The combin ed organic extracts were washed with brine, dried $\left(\mathrm{MgSO}_{4}\right)$, filtered, and concentrated. The residue was purified on a silica gel column ( $5 \%$ ethyl acetate/hexane) to give acetal $\mathbf{G}$ ( $5.9 \mathrm{~g}$, $22.5 \mathrm{mmol}, 49 \%$ ).

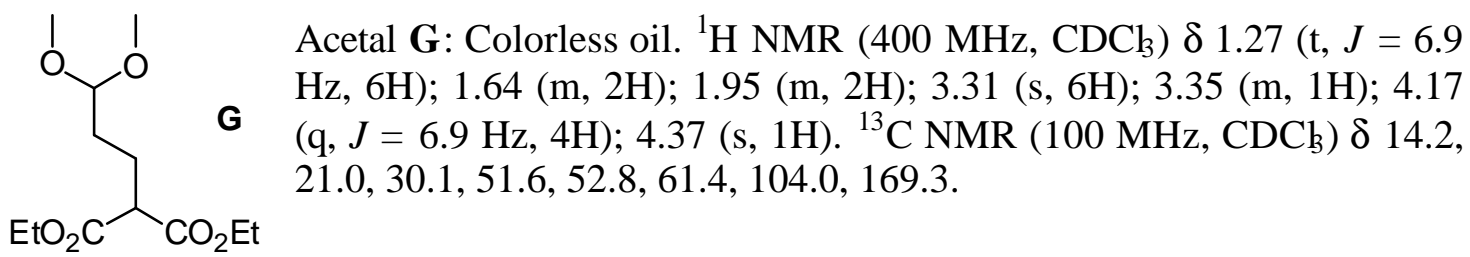

Acetal $\mathbf{H}$. To acetal $\mathbf{G}(2.8 \mathrm{~g}, 10.6 \mathrm{mmol})$ in dry THF $(40 \mathrm{~mL})$ was added sodium hydride $(0.33 \mathrm{~g}, 13.7 \mathrm{mmol})$ at $0^{\circ} \mathrm{C}$ and the mixture was allowed to warm to room temperature until gas evolution ceased. After the addition of 1,2-dibromo-ethane ( $22 \mathrm{mmol}, 2.0 \mathrm{~mL}$ ) the mixture was refluxed for $24 \mathrm{~h}$. Additional 1,2-dibromo-ethane $(1 \mathrm{~mL})$ was added and the mixture was refluxed for further $12 \mathrm{~h}$. After the mixture was allowed to cool down to rt dichloromethane and water were added and the aqueous phase was extracted with dichloromethane. The combined organic extracts were washed with brine, dried 
$\left(\mathrm{MgSO}_{4}\right)$, filtered, and concentrated. The residue was purified on a silica gel column (5\% ethyl acetate/hexane) to give acetal $\mathbf{H}(2 \mathrm{~g}, 51 \%)$.

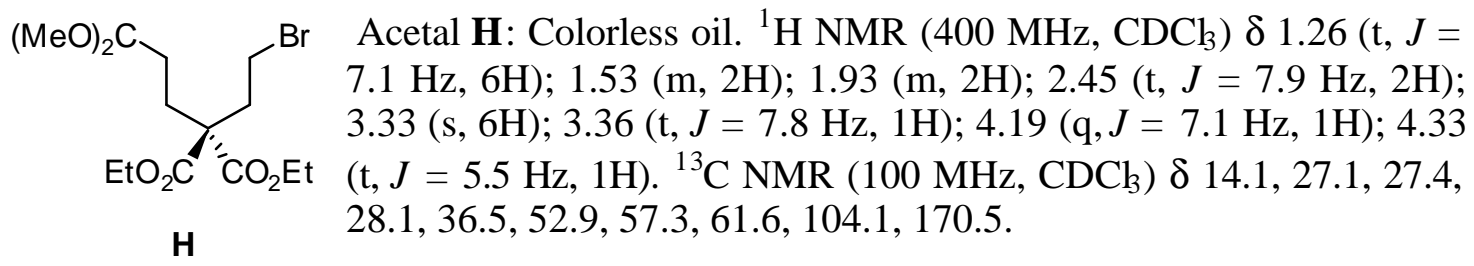

Aldehyde 15. To acetal $\mathbf{H}(2 \mathrm{~g}, 5.4 \mathrm{mmol})$ in acetone $(5 \mathrm{~mL})$ and water $(5 \mathrm{~mL})$ was added $p$-toluene-sulfonic acid $(0.81 \mathrm{mmol}, 0.14 \mathrm{~g})$ and the mixture was refluxed for $2 \mathrm{~h}$ After the mixture was allowed to cool down to rt dichloromethane and water were added and the aqueous phase was extracted with dichloromethane. The combined organic extracts were washed with saturated aqueous $\mathrm{NaHCO}_{3}$-solution, dried $\left(\mathrm{MgSO}_{4}\right)$, filtered, and concentrated. The residue was purified on a silica gel column (5\% ethyl acetate/hexane) to give aldehyde 15 (1.2 g, $3.7 \mathrm{mmol}, 68 \%)$.

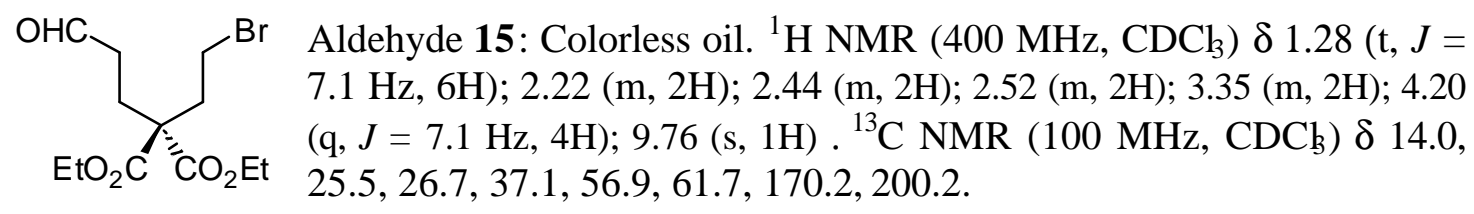

15<smiles>COCC(CN)OC</smiles>
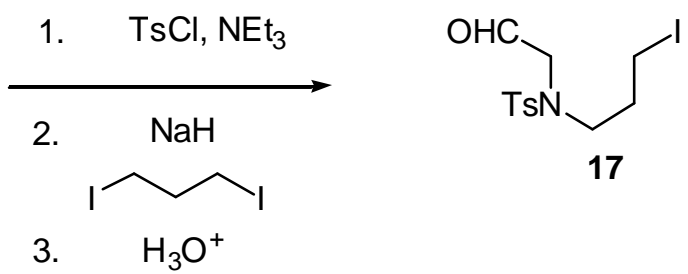

Acetal I. A solution of triethylamine $(150 \mathrm{mmol}, 20 \mathrm{~mL})$ and 2,2-dimethoxy-ethylamine $(50 \mathrm{mmol}, 5.5 \mathrm{~g})$ in dry dichloromethane $(100 \mathrm{~mL})$ was cooled to $0^{\circ} \mathrm{C}$ and $p$ toluenesulfonyl chloride $(50 \mathrm{mmol}, 9.5 \mathrm{~g})$ was added to the solution. After $24 \mathrm{~h}$ dichloromethane and water were added and the aqueous phase was extracted with dichloromethane. The combined organic extracts were washed with brine, dried $\left(\mathrm{MgSO}_{4}\right)$, filtered, and concentrated. The residue was purified on a silica gel column (25\% ethyl acetate/hexane) to give acetal I (10.6 g, $41 \mathrm{mmol}, 82 \%)$.

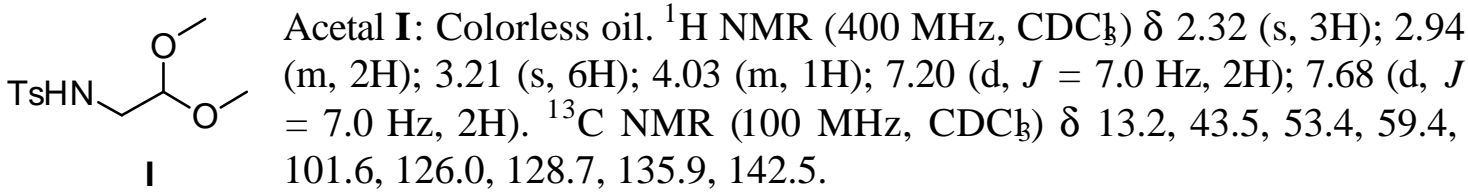

Acetal J. To acetal I (4 g, $15.4 \mathrm{mmol})$ in dry THF (90 mL) was added sodium hydride $(0.4 \mathrm{~g}, 16.7 \mathrm{mmol})$ at $0^{\circ} \mathrm{C}$ and the mixture was allowed to warm to rt until gas evolution 
ceased. After the addition of 1,3-diiodo-propane $(30 \mathrm{mmol}, 3.4 \mathrm{~mL})$ the mixture was refluxed for $24 \mathrm{~h}$. Additional 1,3-diiodo-propane $(1 \mathrm{~mL})$ was added and the mixture was refluxed for further $12 \mathrm{~h}$. After the mixture was allowed to cool down to $\mathrm{rt}$ dichloromethane and water were added and the aqueous phase was extracted with dichloromethane. The combined organic extracts were washed with brine, dried $\left(\mathrm{MgSO}_{4}\right)$, filtered, and concentrated. The residue was purified on a silica gel column ( $25 \%$ ethyl acetate/hexane) to give acetal $\mathbf{H}(3.0 \mathrm{~g}, 10 \mathrm{mmol}, 65 \%)$.

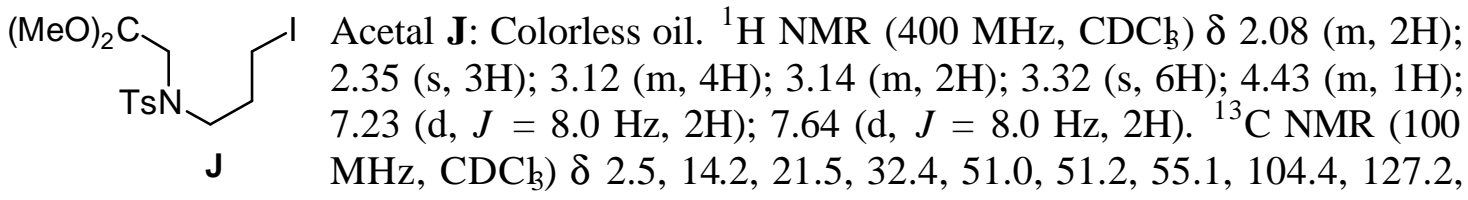
$129.8,137.3,143.5$.

Aldehyde 17. To acetal $\mathbf{J}(2.8 \mathrm{~g}, 9.4 \mathrm{mmol})$ in acetone $(30 \mathrm{~mL})$ was added an aqueous solution of $\mathrm{HCl}(4 \mathrm{~N})$ and the mixture was stirred for $48 \mathrm{~h}$. Dichloromethane and water were added and the aqueous phase was extracted with dichloromethane. The combined organic extracts were washed with saturated aqueous $\mathrm{NaHCO}_{3}$-solution, dried $\left(\mathrm{MgSO}_{4}\right)$, filtered, and concentrated. The residue was purified on a silica gel column (25\% ethyl acetate/hexane) to give aldehyde 17 ( $1.9 \mathrm{~g}, 5.0 \mathrm{mmol}, 53 \%)$.

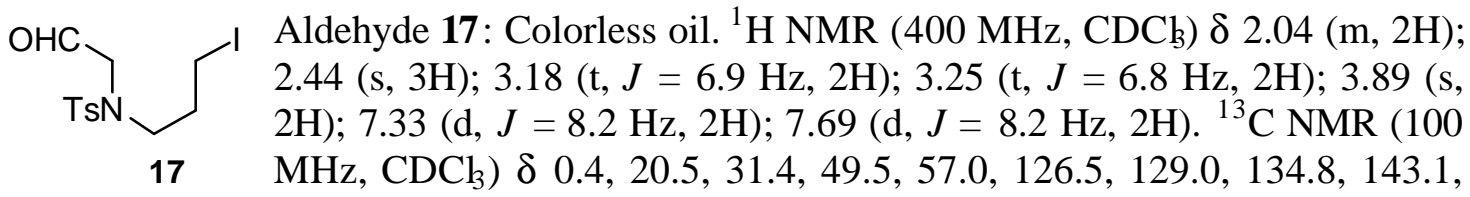
196.3 .

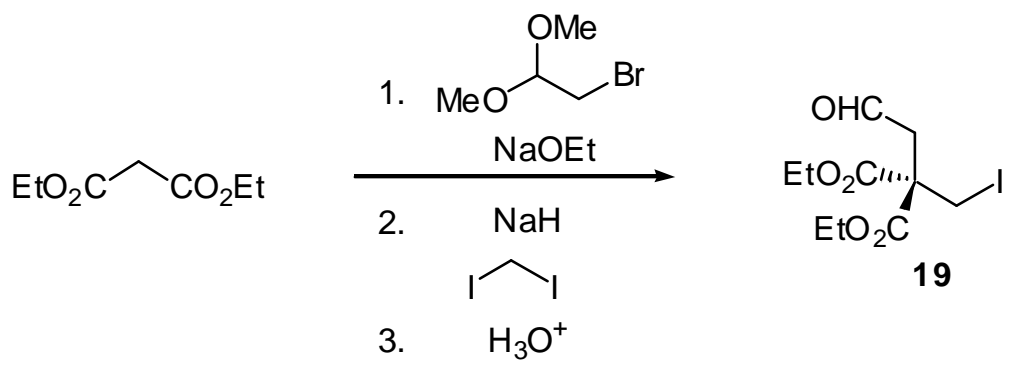

Acetal K. To acetal A (3 g, $12 \mathrm{mmol})$ in dry THF $(60 \mathrm{~mL})$ was added sodium hydride $(0.32 \mathrm{~g}, 13.2 \mathrm{mmol})$ at $0^{\circ} \mathrm{C}$ and the mixture was allowed to warm to room temperature until gas evolution ceased. After the addition of diiodomethane $(24 \mathrm{mmol}, 2.0 \mathrm{~mL})$ the mixture was refluxed for $24 \mathrm{~h}$. Additional 1,3-diiodo-propane $(1 \mathrm{~mL})$ was added and the mixture was refluxed for further $12 \mathrm{~h}$. After the mixture was allowed to cool down to $\mathrm{rt}$ dichloromethane and water were added and the aqueous phase was extracted with dichloromethane. The combined organic extracts were washed with brine, dried $\left(\mathrm{MgSO}_{4}\right)$, filtered, and concentrated. The residue was purified on a silica gel column $(5 \%$ ethyl acetate/hexane) to give acetal $\mathbf{K}(2.3 \mathrm{~g}, 6.3 \mathrm{mmol}, 52 \%)$. 


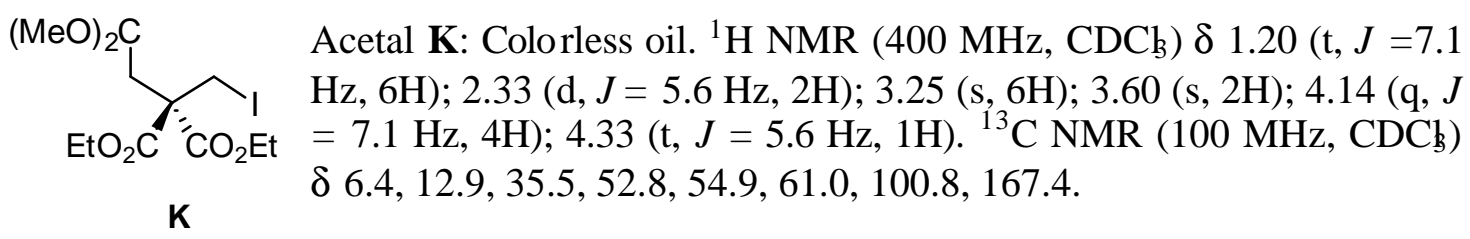

Aldehyde 19. To acetal $\mathbf{K}(2 \mathrm{~g}, 5.5 \mathrm{mmol})$ in acetone $(6 \mathrm{~mL})$ and water $(6 \mathrm{~mL})$ was added $p$-toluene-sulfonic acid $(0.72 \mathrm{mmol}, 0.12 \mathrm{~g})$ and the mixture was refluxed for $2 \mathrm{~h}$ After the mixture was allowed to cool down to rt dichloromethane and water were added and the aqueous phase was extracted with dichloromethane. The combined organic extracts were washed with saturated aqueous $\mathrm{NaHCO}_{3}$-solution, dried $\left(\mathrm{MgSO}_{4}\right)$, filtered, and concentrated. The residue was purified on a silica gel column (5\% ethyl acetate/hexane) to give aldehyde $9(1.1 \mathrm{~g}, 3.0 \mathrm{mmol}, 55 \%)$.

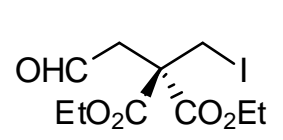

19

Aldehyde 19: Colorless oil. ${ }^{1} \mathrm{H}$ NMR $\left(300 \mathrm{MHz}, \mathrm{CDCl}_{3}\right) \delta 1.27(\mathrm{t}, \mathrm{J} 0$ $7.1 \mathrm{~Hz}, 6 \mathrm{H}) ; 3.29(\mathrm{~s}, 2 \mathrm{H}) ; 3.79(\mathrm{~s}, 2 \mathrm{H}) ; 4.22(\mathrm{q}, J=7.1 \mathrm{~Hz}, 4 \mathrm{H}) ; 9.74$ (s, 1H). ${ }^{13} \mathrm{C}$ NMR $\left(75 \mathrm{MHz}, \mathrm{CDCl}_{3}\right) \delta 7.4,14.5,48.0,63.2,167.5$, 198.7.

\section{Asymmetric $\alpha$-Alkylations:}

Procedure [1]. Reactions in chloroform. A solution of the aldehyde $(0.5 \mathrm{mmol})$ in dry chloroform $(2.5 \mathrm{~mL})$ was added to the catalyst $((S)$ - or $(R)$ - $\alpha$-methylproline, $5-20 \mathrm{~mol} \%)$ and the mixture was cooled to $-30^{\circ} \mathrm{C}$. After the addition of triethylamine $(0.5 \mathrm{mmol}, 70$ $\mu \mathrm{L})$ the mixture was stirred for 24-48 $\mathrm{h}$. The mixture was filtered and concentrated. The residue was purified on a silica gel column (20\% ethyl acetate/hexane) to give the pure aldehyde.

The synthesis of the racemic compounds was performed according to procedure [1] at room temperature with ( $\mathrm{rac}$ )-proline $(25 \mathrm{~mol} \%)$.

Procedure [2]. Reactions in mesitylene. A solution of the aldehyde $(0.5 \mathrm{mmol})$ in dry mesitylene $(2.5 \mathrm{~mL})$ was added to the catalyst $((S)$ - or $(R)$ - $\alpha$-methylproline, $20 \mathrm{~mol} \%)$ and the mixture was cooled to $-15^{\circ} \mathrm{C}$. After the addition of triethylamine $(0.5 \mathrm{mmol}, 70$ $\mu \mathrm{L})$ the mixture was stirred for $216 \mathrm{~h}$. The mixture was filtered and concentrated. The residue was purified on a silica gel column (20\% ethyl acetate/hexane) to give the aldehyde.

\section{Enantiomeric Excess-Determination:}

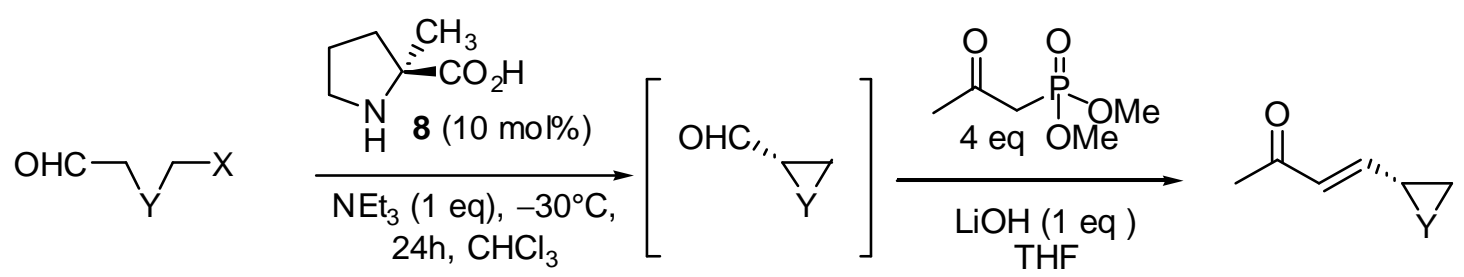


(2-Oxo-propyl)-phosphonic acid diethyl ester $(2 \mathrm{mmol}, 0.3 \mathrm{~mL})$ was added to lithium hydroxide monohydrate $(0.5 \mathrm{mmol}, 21 \mathrm{mg})$ in THF $(3 \mathrm{~mL})$ and the mixture was stirred for $30 \mathrm{~min}$. After the addition of the reaction mixtures from procedures [1] or [2] the resulting mixture was stirred for further $30 \mathrm{~min}$. The resulting enone was isolated through preparative TLC and analyzed by chiral stationary phase HPLC.

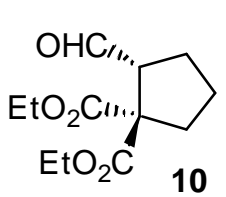

Aldehyde 10: Colorless oil (111 mg, $0.46 \mathrm{mmol}, 92 \%$, from iodide 9), (109 mg, $0.45 \mathrm{mmol}, 90 \%$, from bromide $\mathbf{1 1} / 24 \mathrm{mg}, 0.1 \mathrm{mmol}, 20 \%$ from tosylate 12). HRMS (ESI) calcd for $\mathrm{MNa}^{+}$265.1052, found 265.1053. HPLC (enone derivative, Chiralpak AS-RH, 78\% $\mathrm{H}_{2} \mathrm{O} 22 \%$ $\mathrm{CH}_{3} \mathrm{CN}$ ) $\mathrm{t}_{\mathrm{r}}(S)=108.8$ min, $\mathrm{t}_{\mathrm{r}}(R)=122.6$ min, $e e=95 \%$ (from iodide 9); $e e=94 \%$ (from bromide 11); $e e=91 \%$ (from tosylate 12). ${ }^{1} \mathrm{H}$ NMR $(400 \mathrm{MHz}, \mathrm{CDCb})$ $\delta 1.22(\mathrm{~m}, 6 \mathrm{H}) ; 1.71-1.79(\mathrm{~m}, 2 \mathrm{H}) ; 1.98-2.04(\mathrm{~m}, 2 \mathrm{H}) ; 2.22-2.25(\mathrm{~m}, 1 \mathrm{H}) ; 2.36-2.39(\mathrm{~m}$, $1 \mathrm{H}) ; 3.26(\mathrm{t}, \quad J=7.9 \mathrm{~Hz}, 1 \mathrm{H}) ; 4.16-4.21(\mathrm{~m}, 2 \mathrm{H}) ; 4.22-4.28(\mathrm{~m}, 2 \mathrm{H}) .{ }^{13} \mathrm{C}$ NMR $(100$ $\left.\mathrm{MHz}, \mathrm{CDCl}_{3}\right) \delta 14.0,22.7,25.1,34.6,57.5,62.0,62.6,170.1,171.1,200.0$.

Aldehyde 14: Yellow oil (172 mg, 0.47 mmol, 94\%). HRMS (ESI) calcd<smiles>CC(C(=O)Br)(C(=O)OBr)[C@H]1CCC[C@@H]1C=O</smiles>
for $\mathrm{MNa}^{+} 389.1365$, found 389.1364. HPLC (enone derivative, Chiralpak AS-RH, 60\% $\left.\mathrm{H}_{2} \mathrm{O} 40 \% \mathrm{CH}_{3} \mathrm{CN}\right) \mathrm{t}_{\mathrm{r}}(S)=73.5 \mathrm{~min}, \mathrm{t}_{\mathrm{r}}(R)=79.8 \mathrm{~min}, e e=$ 95\%. ${ }^{1} \mathrm{H}$ NMR $\left(400 \mathrm{MHz}, \mathrm{CDCl}_{3}\right) \delta 1.60-1.67(\mathrm{~m}, 2 \mathrm{H}) ; 1.89-1.95(\mathrm{~m}$, $2 \mathrm{H}) ; 2.18-2.23(\mathrm{~m}, 1 \mathrm{H}) ; 2.29-2.32(\mathrm{~m}, 1 \mathrm{H}) ; 3.20(\mathrm{t}, J=7.8 \mathrm{~Hz}, 1 \mathrm{H})$; 4.96-5.07 (m, 4H); 7.13-7.28 (m, 10H); $9.65(\mathrm{~s}, 1 \mathrm{H}) .{ }^{13} \mathrm{C} \mathrm{NMR}\left(100 \mathrm{MHz}, \mathrm{CDCb}_{3}\right) \delta$ 21.6, 24.1, 33.6, 56.5, 61.6, 66.6, 127.4, 127.5, 127.6, 134.1, 168.8, 169.7, 198.8 .

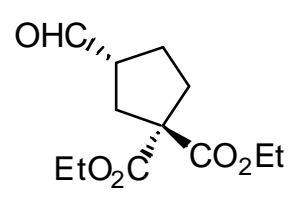

16

Aldehyde 16: Colorless oil (111 mg, $0.46 \mathrm{mmol}, 92 \%$, procedure [2] / $112 \mathrm{mg}, 0.47 \mathrm{mmol}, 93 \%$, procedure [1]). HRMS (CI, isobutane) calcd for $\mathrm{MH}^{+}$243.1233, found 243.1230. HPLC (enone derivative, Chiralpak AD-RH, 65\% $\left.\mathrm{H}_{2} \mathrm{O} 35 \% \mathrm{CH}_{3} \mathrm{CN}\right) \mathrm{t}_{\mathrm{r}}(S)=21.2 \min , \mathrm{t}_{\mathrm{t}}(R)=$ $23.0 \mathrm{~min}$, ee $=96 \%$, procedure [2] $/ 84 \%$, procedure [1]). ${ }^{1} \mathrm{H}$ NMR $\left(400 \mathrm{MHz}, \mathrm{CDCl}_{3}\right) \delta 1.18(\mathrm{~m}, 6 \mathrm{H}) ; 1.88-1.94(\mathrm{~m}, 2 \mathrm{H}) ; 2.18(\mathrm{~m}, 2 \mathrm{H})$; 2.36-2.44 (m, 2H); $2.84(\mathrm{~m}, 1 \mathrm{H}) ; 4.08-4.15(\mathrm{~m}, 4 \mathrm{H}) ; 9.57(\mathrm{~s}, 1 \mathrm{H}) .{ }^{13} \mathrm{C}$ NMR $(100 \mathrm{MHz}$, $\left.\mathrm{CDCl}_{3}\right) \delta 13.6,25.2,33.3,50.4,59.9,61.3,171.1,201.7$.

Aldehyde $17(0.5 \mathrm{mmol}, 191 \mathrm{mg})$ in dry chloroform $(2.5 \mathrm{~mL})$ was added to the catalyst ( $\alpha$-methylproline, $15 \mathrm{~mol} \%$ ) and the mixture was cooled to $-30^{\circ} \mathrm{C}$. After the addition of triethylamine $(0.5 \mathrm{mmol}, 70 \mu \mathrm{L})$ the mixture was stirred for $24 \mathrm{~h}$. The mixture was then poured to $\mathrm{NaBH}_{4}(0.5 \mathrm{mmol}, 19 \mathrm{mg})$ in methanol $(2.5 \mathrm{~mL})$ and st irred for further $1 \mathrm{~h}$. Dichloromethane and water were added and the aqueous phase was extracted with dichloromethane. The combined organic extracts were washed with saturated aqueous $\mathrm{NH}_{4} \mathrm{Cl}$-solution, dried $\left(\mathrm{MgSO}_{4}\right)$, filtered, and concentrated. The residue was purified on a silica gel column (10\% ethyl acetate/hexane) to give the alcohol 18a.

Alcohol 18a: Colorless solid (66 mg, $0.26 \mathrm{mmol}, 52 \%)$. HRMS (ESI)

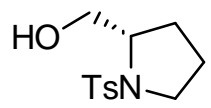

$18 \mathbf{a}$ calcd for $\mathrm{MNa}^{+}$278.0827, found 278.0825. HPLC (Chiralpak AD-RH, $\left.65 \% \mathrm{H}_{2} \mathrm{O} 35 \% \mathrm{CH}_{3} \mathrm{CN}\right) \mathrm{t}_{\mathrm{r}}(S)=21.2 \mathrm{~min}, \mathrm{t}_{\mathrm{r}}(R)=23.0 \mathrm{~min}, e e=91 \%$. $[\alpha]_{\mathrm{D}}^{25}=-78.9^{\circ}(\mathrm{c}=1.0, \mathrm{MeOH})$; Literature: $[\alpha]_{\mathrm{D}}=-89.4^{\circ}(\mathrm{c}=1$, 
$\mathrm{MeOH}) .{ }^{1} \mathrm{H}$ NMR (400 MHz, CDCb) $\delta 1.39(\mathrm{~m}, 1 \mathrm{H}) ; 1.63(\mathrm{~m}, 2 \mathrm{H}) ; 1.71(\mathrm{~m}, 1 \mathrm{H}) ; 2.40$ $(\mathrm{s}, 1 \mathrm{H}) ; 2.37(\mathrm{~s}, 3 \mathrm{H}) ; 3.22(\mathrm{~m}, 2 \mathrm{H}) ; 3.39(\mathrm{~m}, 1 \mathrm{H}) ; 3.58(\mathrm{~m}, 2 \mathrm{H}) ; 7.26(\mathrm{~d}, J=8.2 \mathrm{~Hz}, 2 \mathrm{H})$; $7.66(\mathrm{~d}, J=8.2 \mathrm{~Hz}, 2 \mathrm{H}) .{ }^{13} \mathrm{C} \mathrm{NMR}\left(100 \mathrm{MHz}, \mathrm{CDCl}_{3}\right) \delta 19.4,22.1,26.8,47.9,59.7$, $63.7,125.5,127.7,131.8,141.7$.

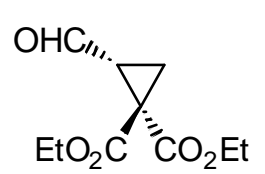

20

195.3.

Aldehyde 20. Colorless oil (75 mg, $0.35 \mathrm{mmol}, 70 \%$, procedure [2]). HRMS (CI, isobutane) calcd for $\mathrm{MH}^{+}$215.0920, found 215.0916. HPLC (enone derivatized, Chiralpak AS-RH, 78\% $\left.\mathrm{H}_{2} \mathrm{O} 22 \% \mathrm{CH}_{3} \mathrm{CN}\right) \mathrm{t}_{\mathrm{r}}(S)=41.5 \mathrm{~min}, \mathrm{t}_{\mathrm{r}}$ $(R)=47.3 \mathrm{~min}, e e=86 \% .{ }^{1} \mathrm{H} \mathrm{NMR}\left(400 \mathrm{MHz}, \mathrm{CDCb}_{3}\right) \delta 1.21(\mathrm{t}, J=6.9 \mathrm{~Hz}$, $6 \mathrm{H}) ; 1.74(\mathrm{~m}, 1 \mathrm{H}) ; 2.00(\mathrm{~m}, 1 \mathrm{H}) ; 2.66(\mathrm{~m}, 1 \mathrm{H}) ; 4.11-4.21(\mathrm{~m}, 4 \mathrm{H}) ; 9.24(\mathrm{~s}$, 1H). ${ }^{13} \mathrm{C}$ NMR $\left(100 \mathrm{MHz}, \mathrm{CDCl}_{3}\right) \delta 12.9,18.2,33.8,61.2,164.9,166.9$, 
NMR-Spectra of the Substrates:
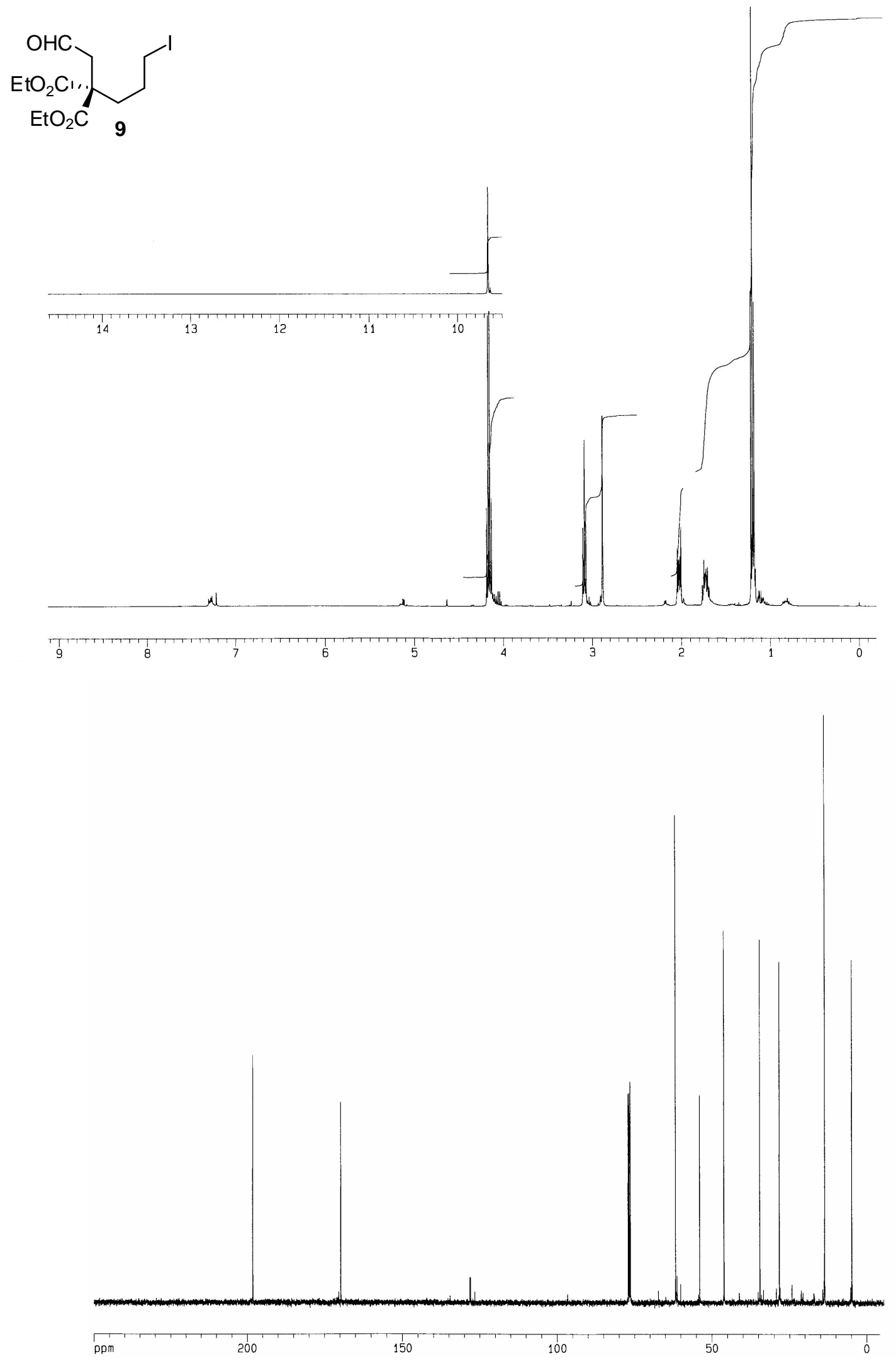
-S 12 -
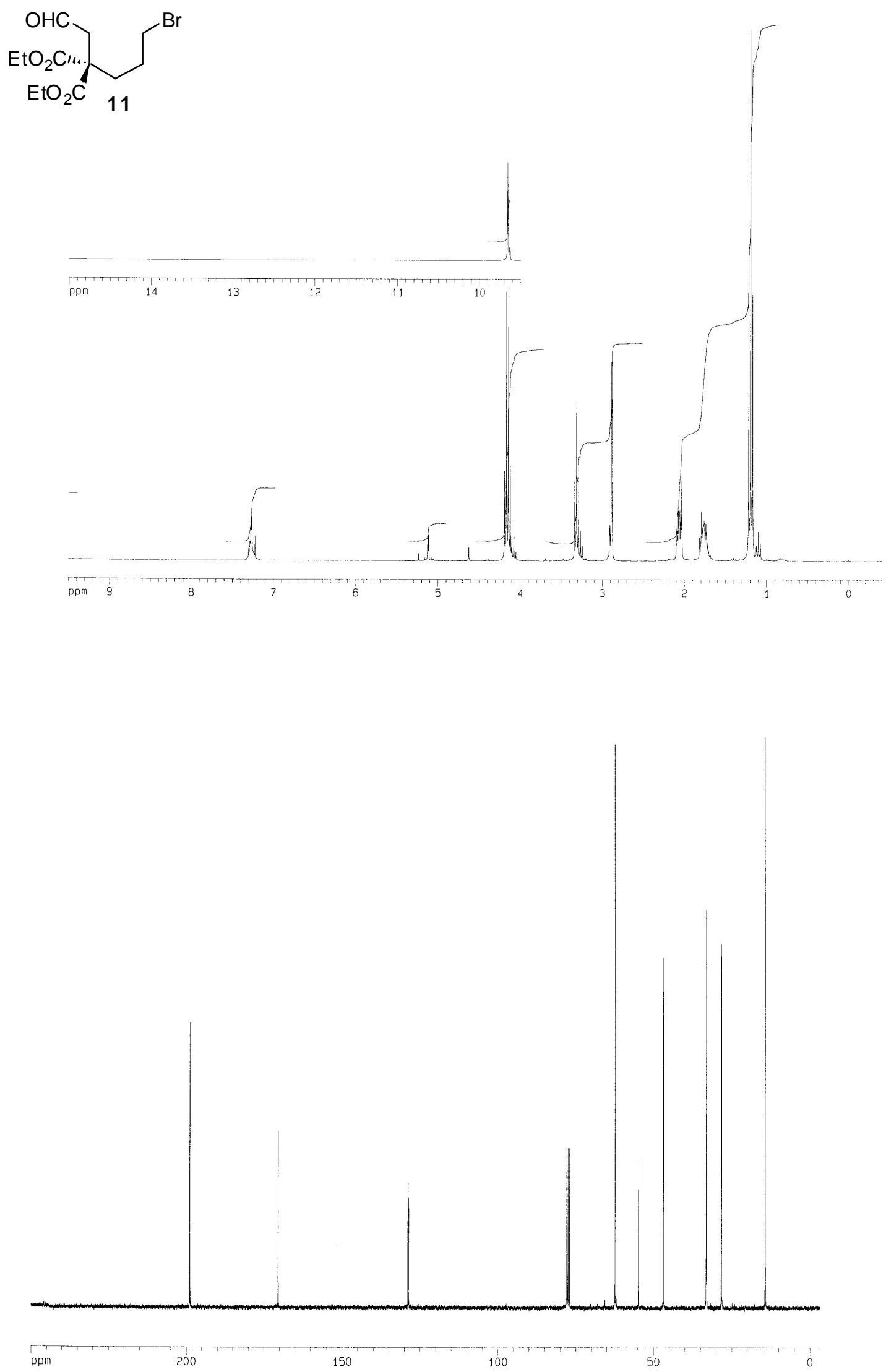

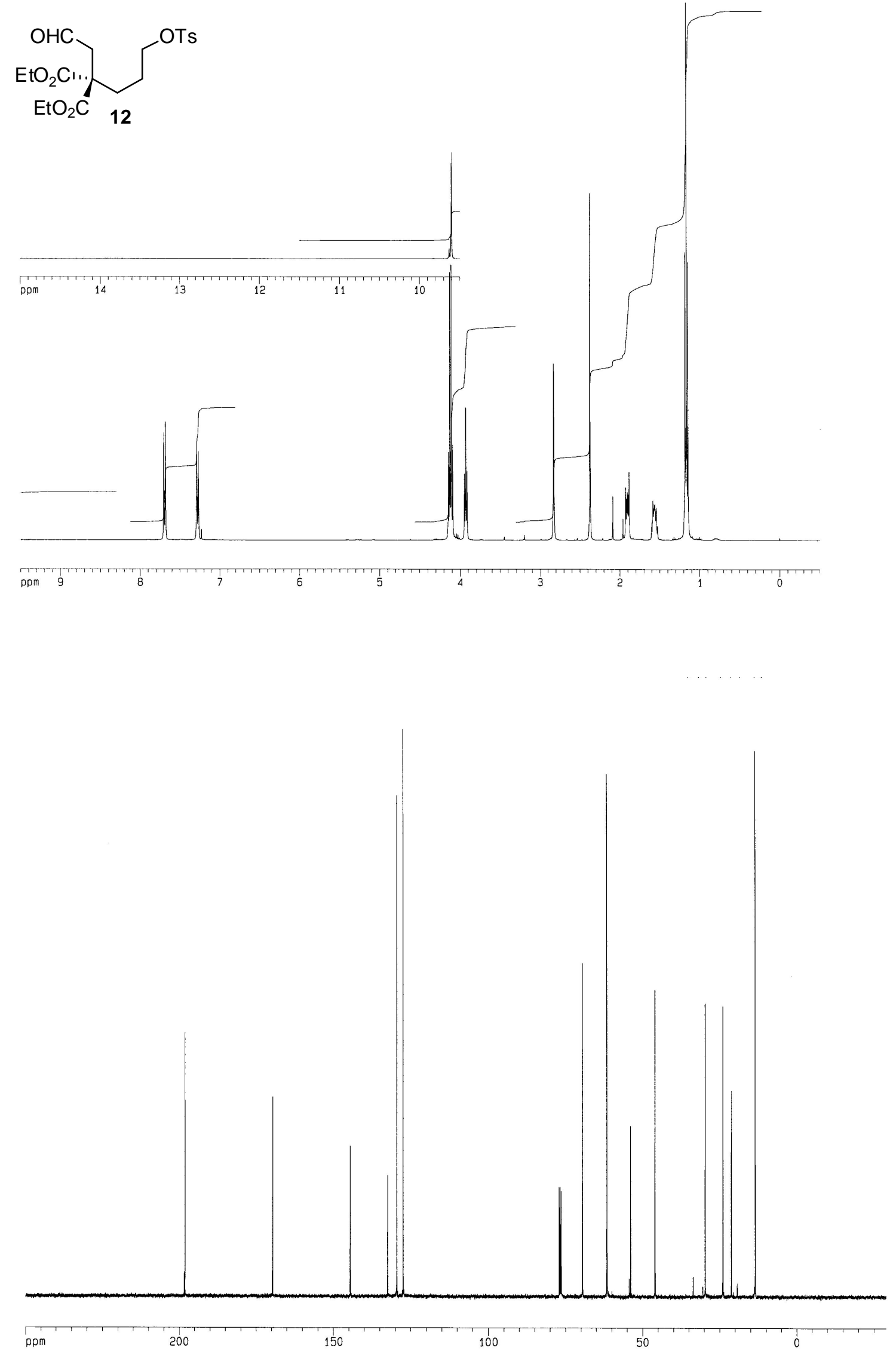
-S14 -
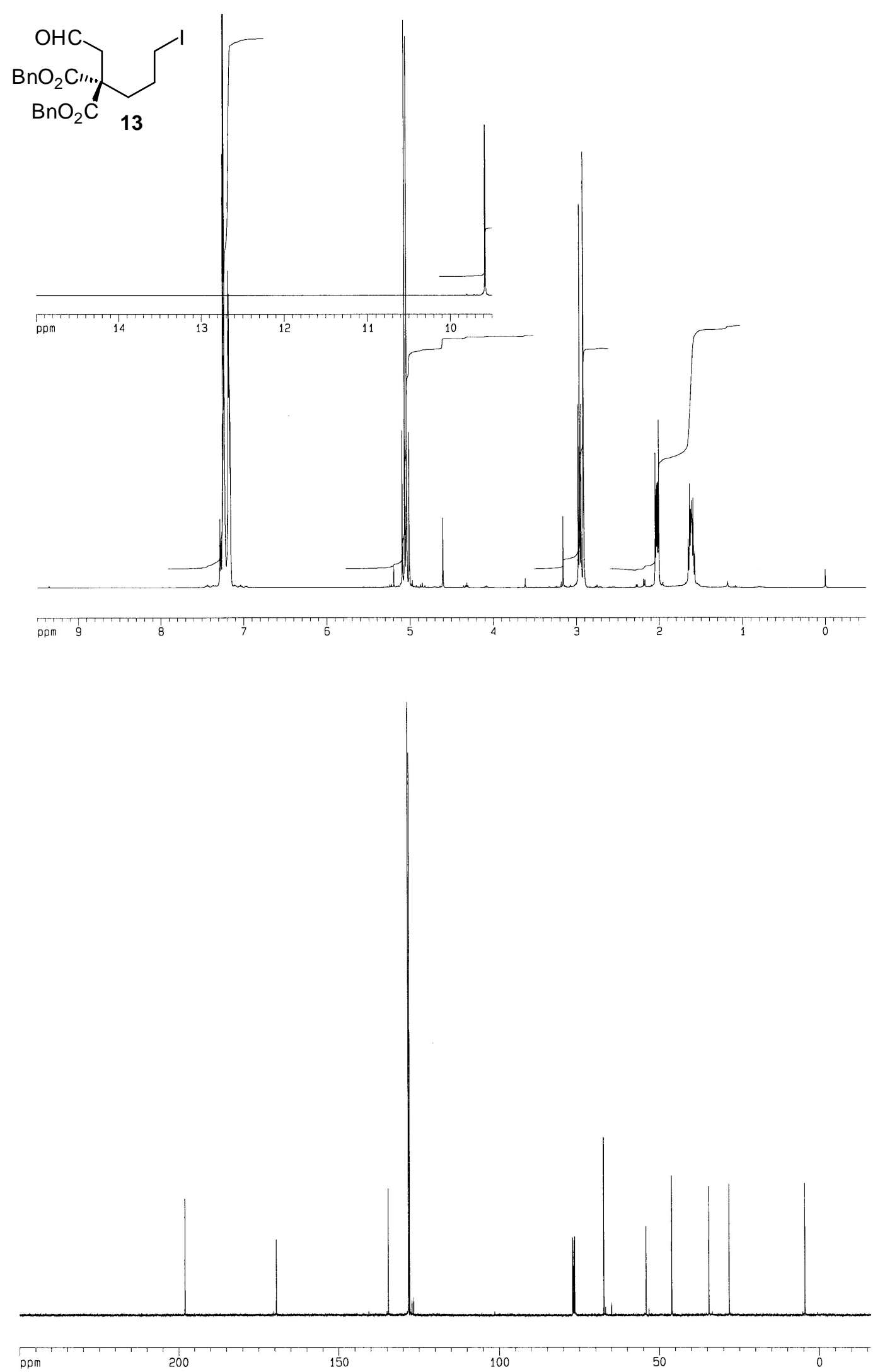


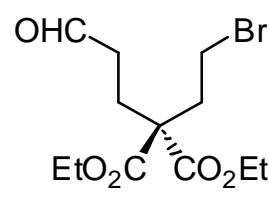

15
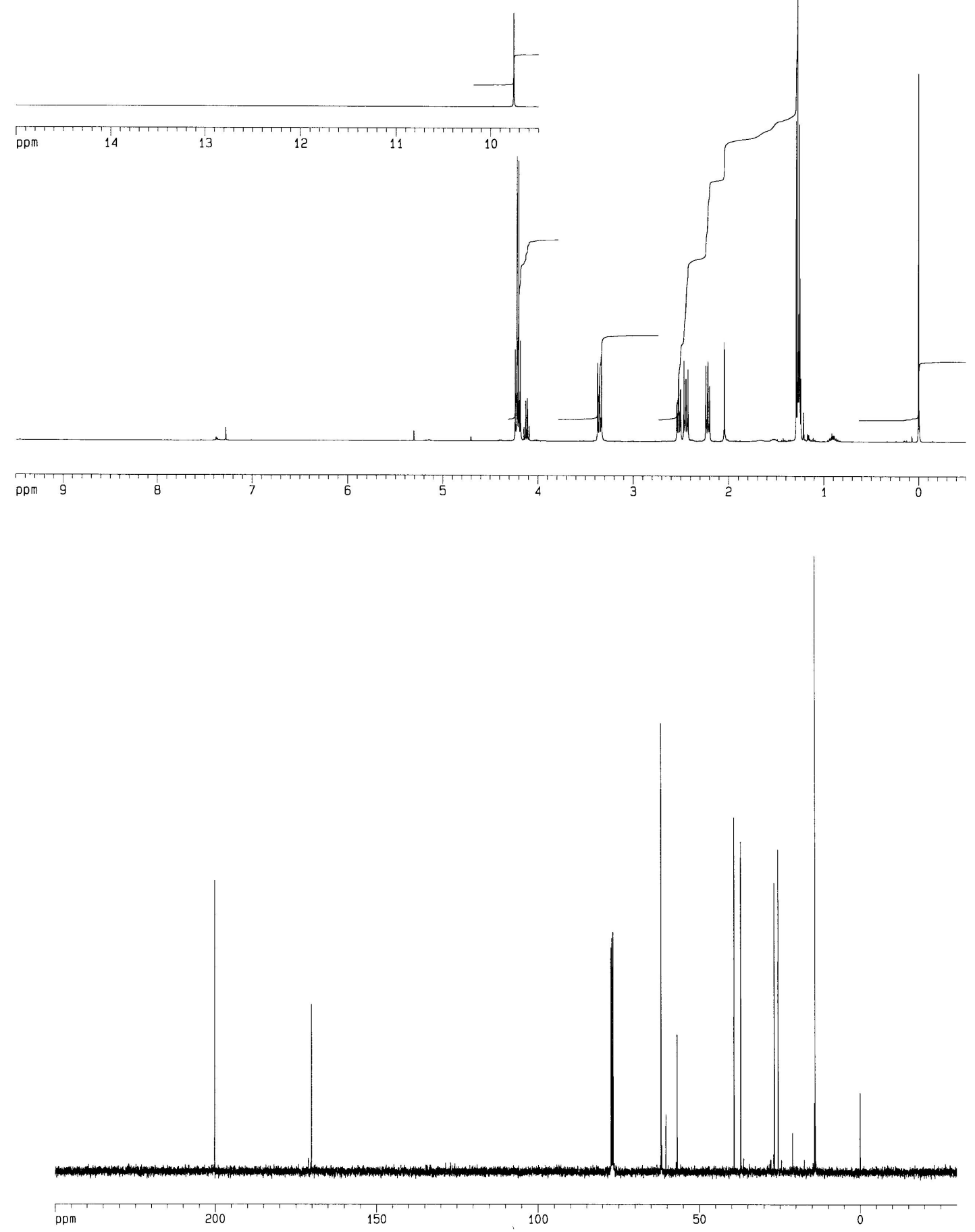

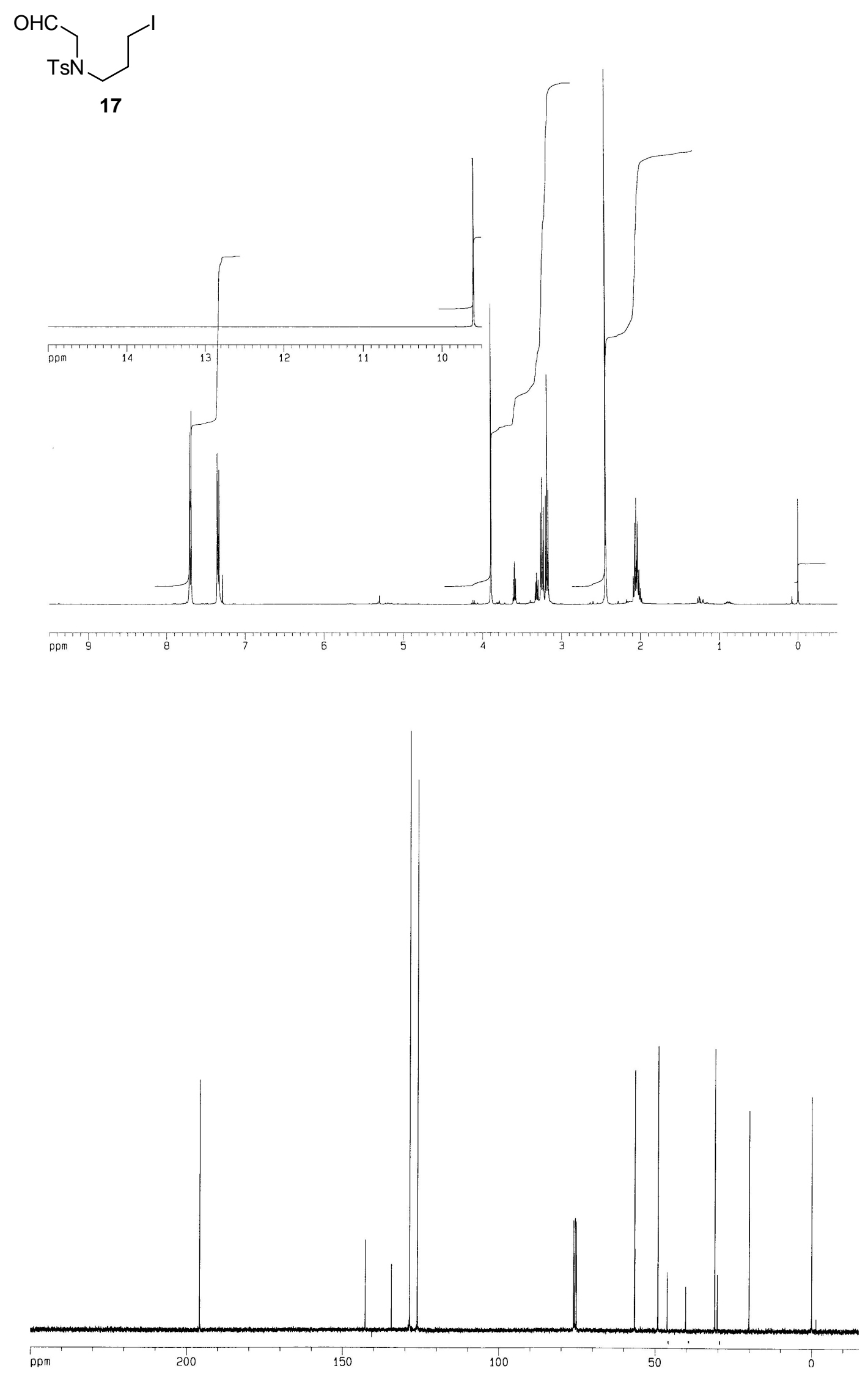

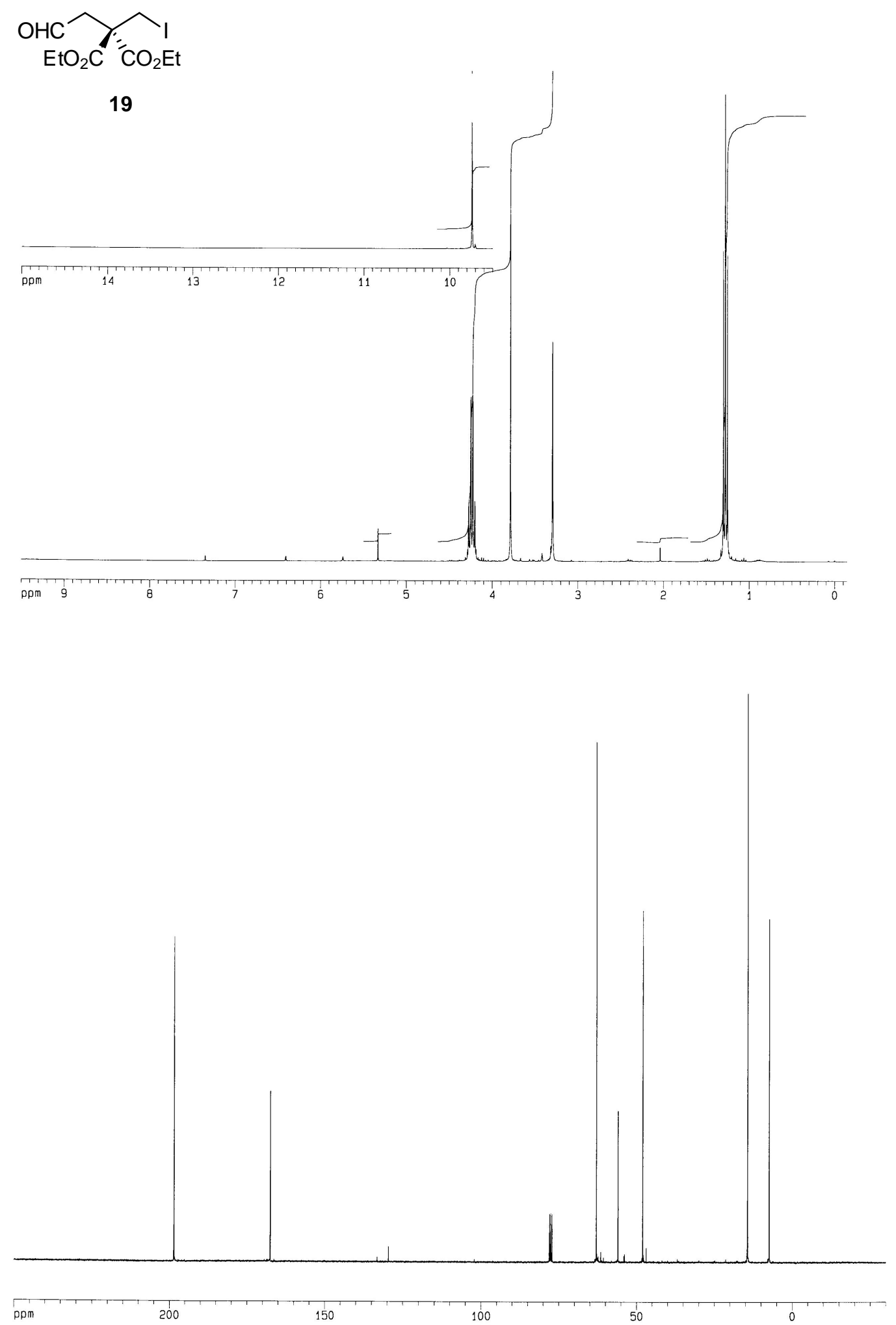
NMR-Spectra and HPLC-Traces of the Alkylation Products:
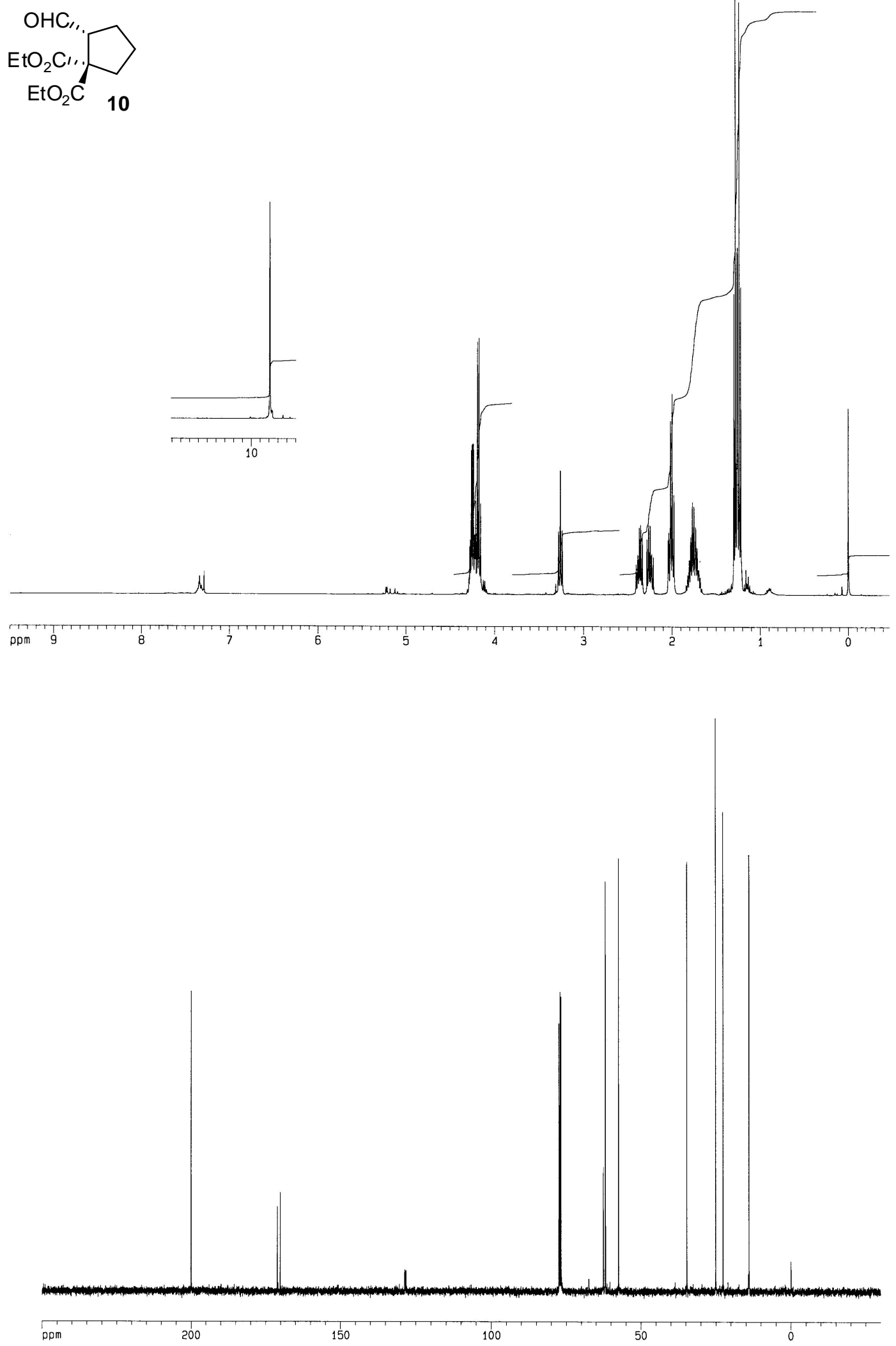

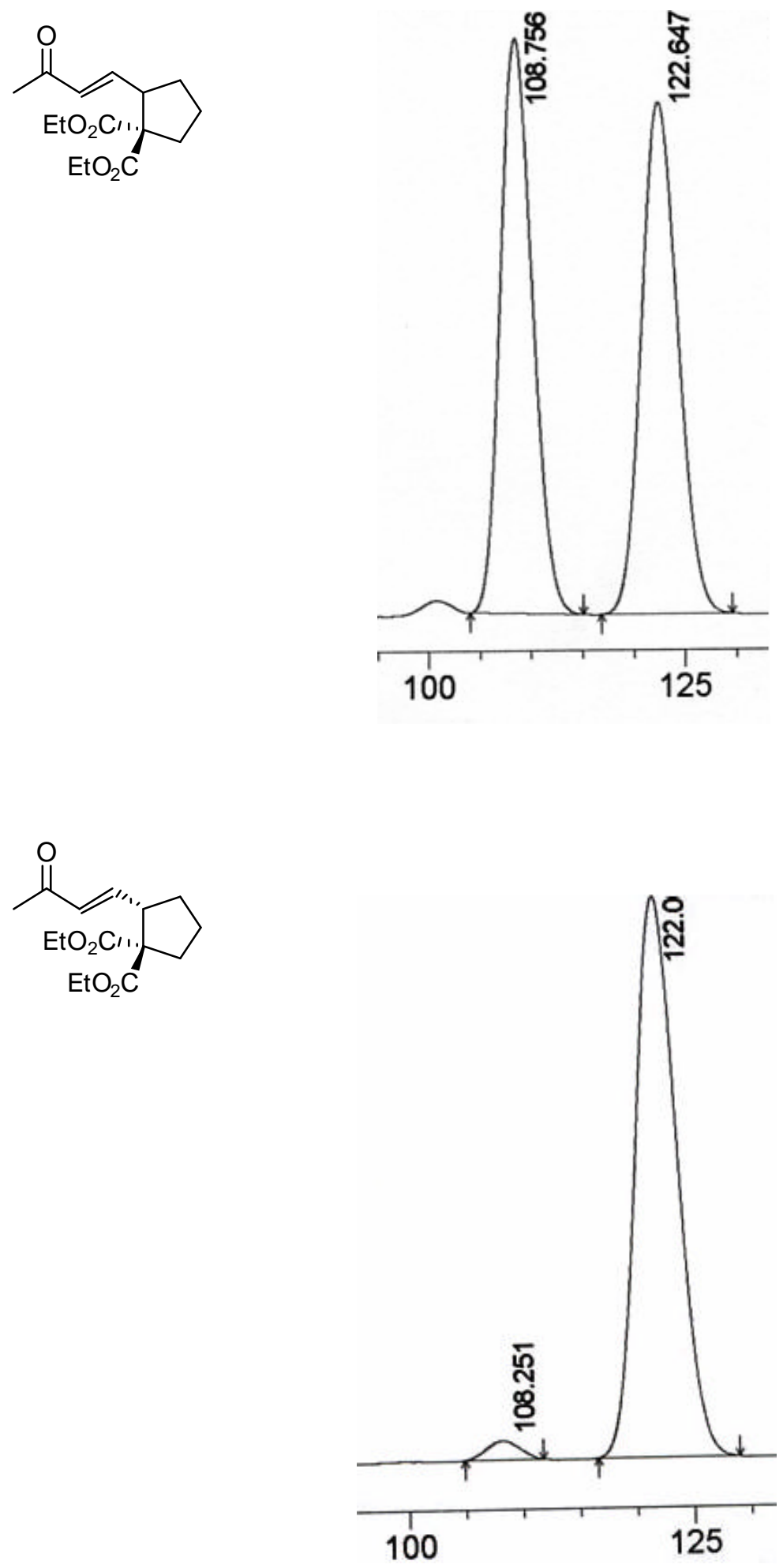


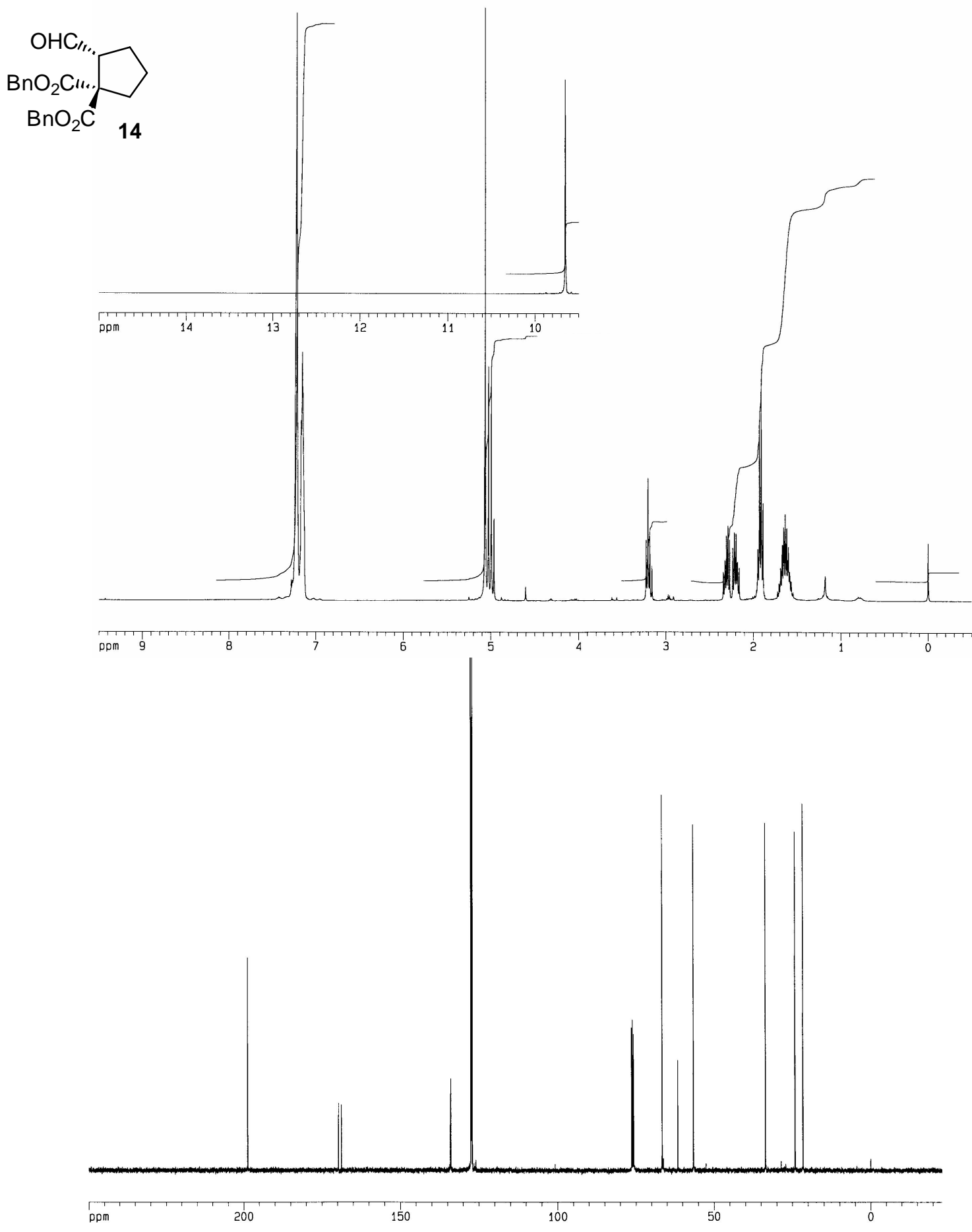



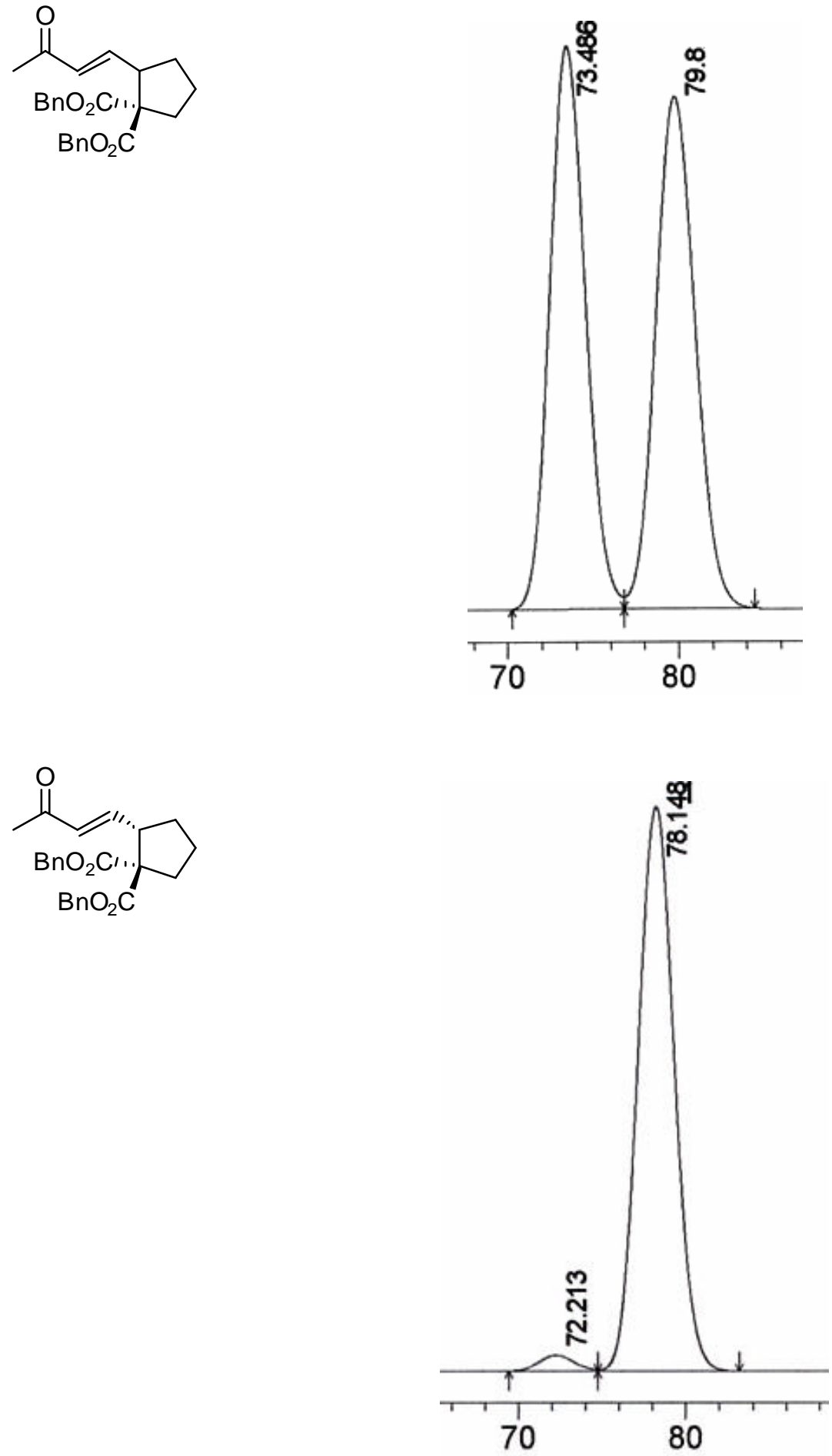

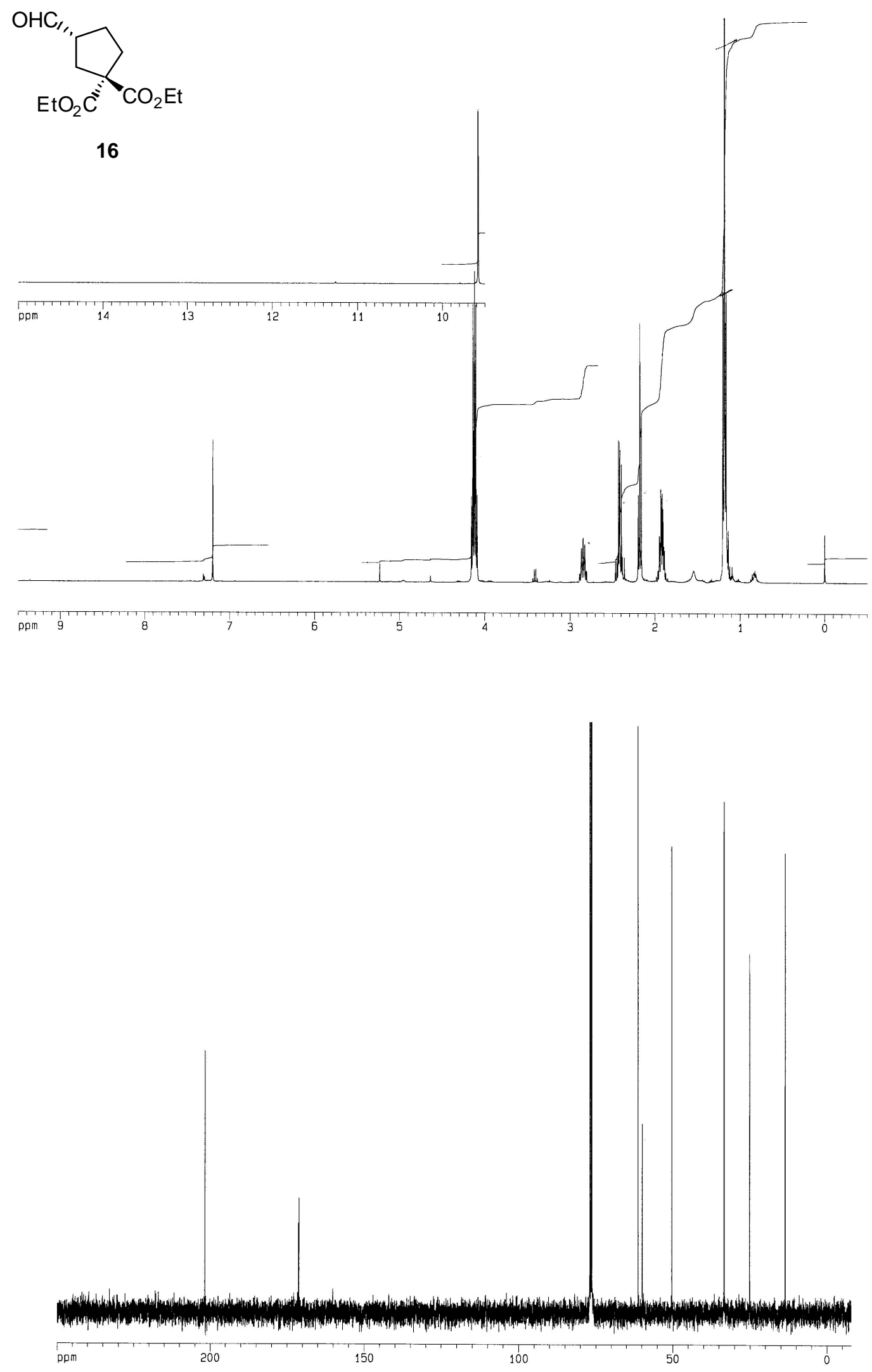

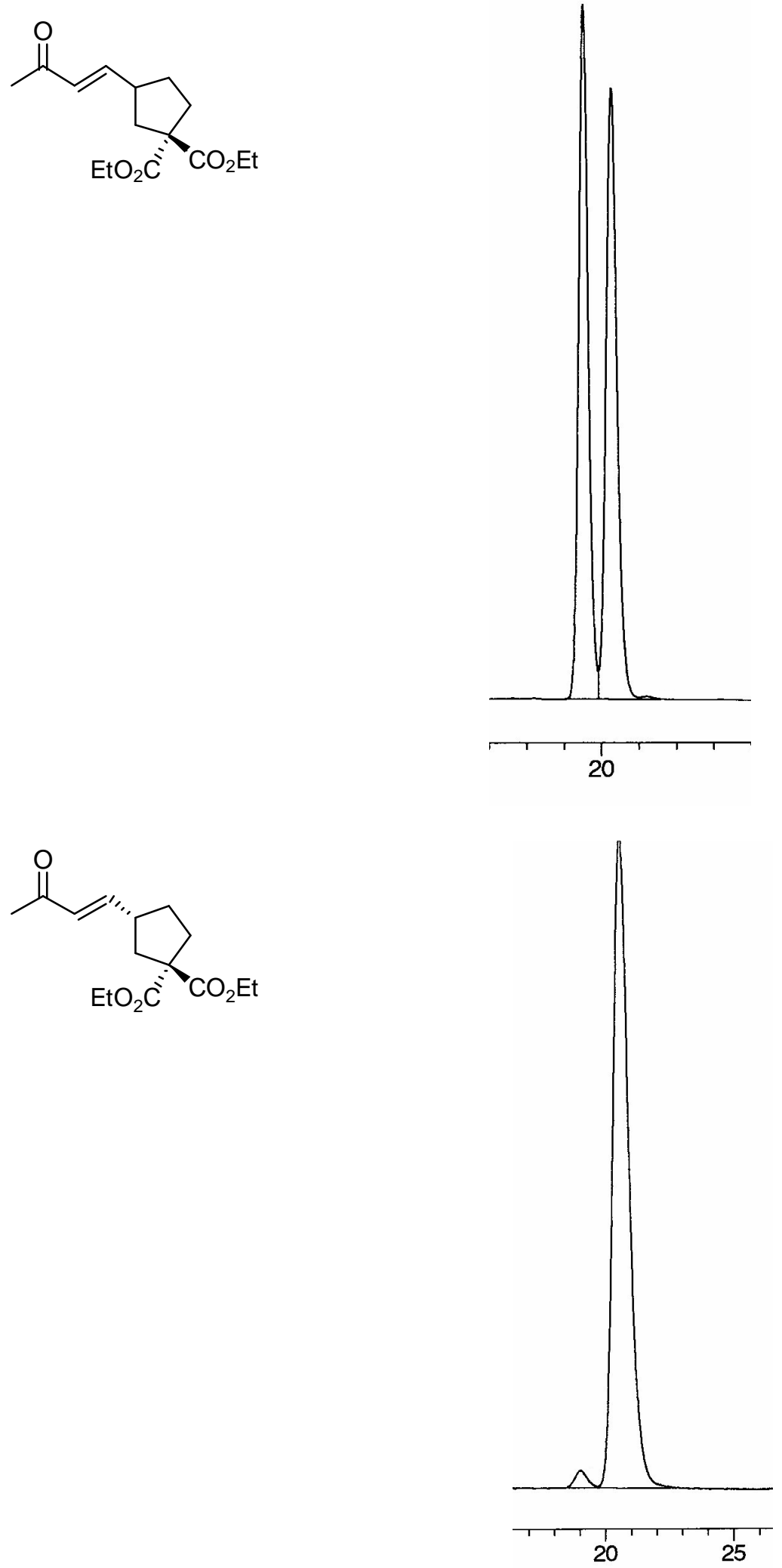
$\mathrm{HO}^{\prime \prime} "$

$18 \mathrm{a}$

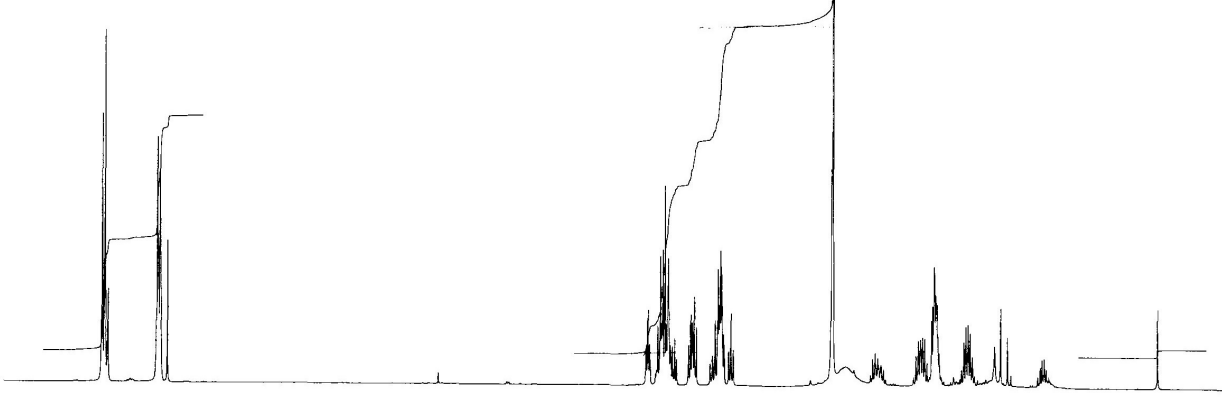

8

6
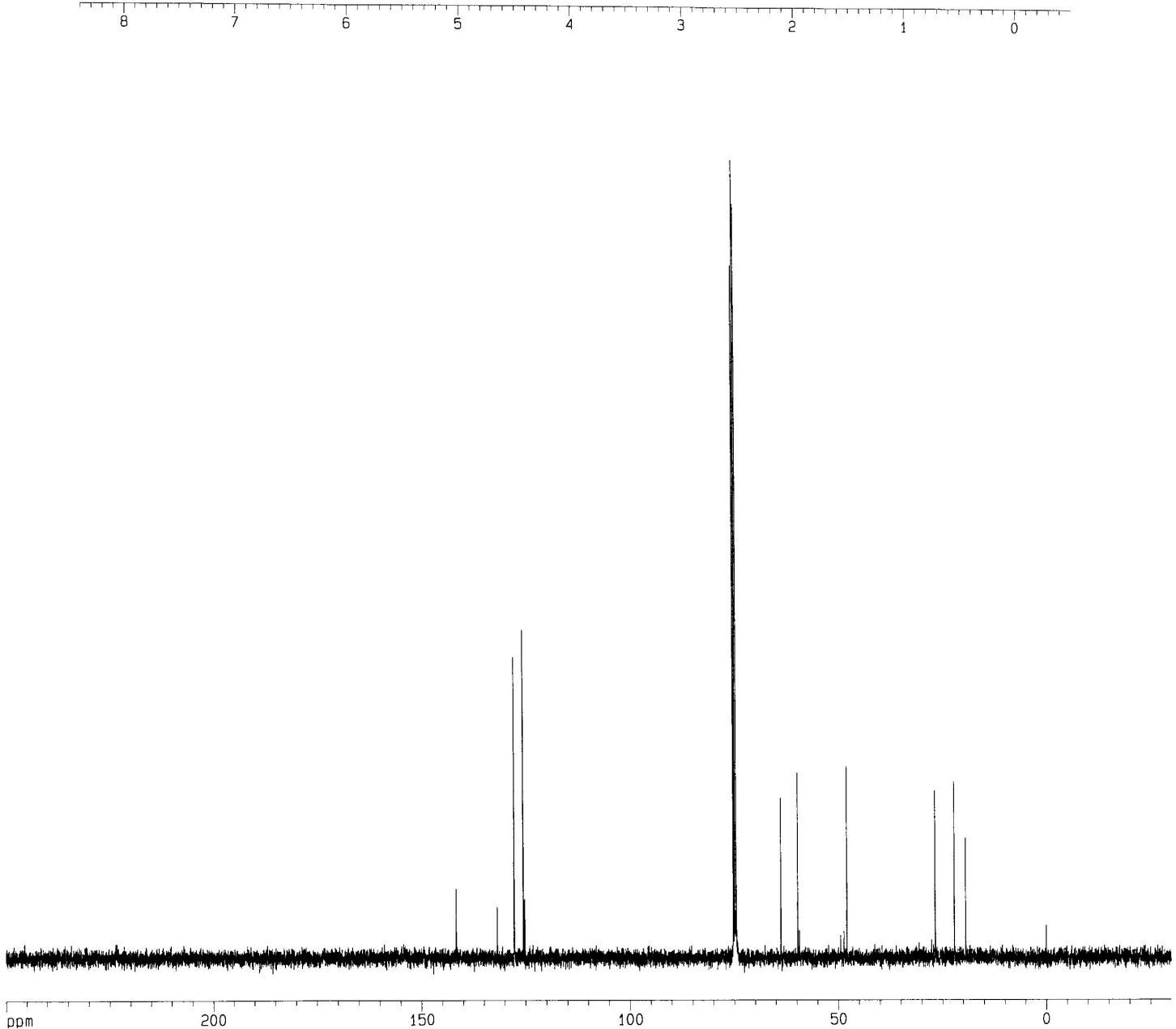

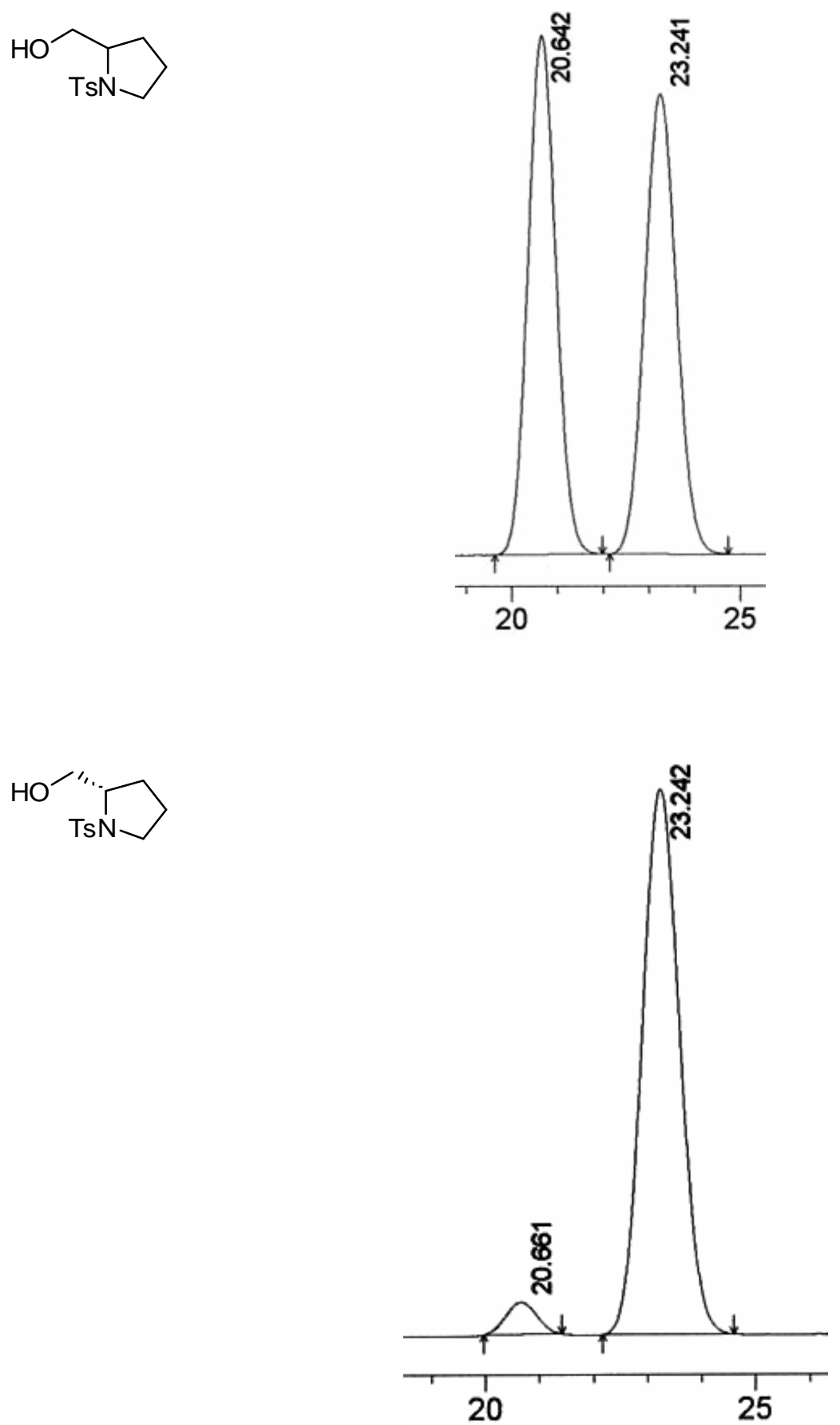

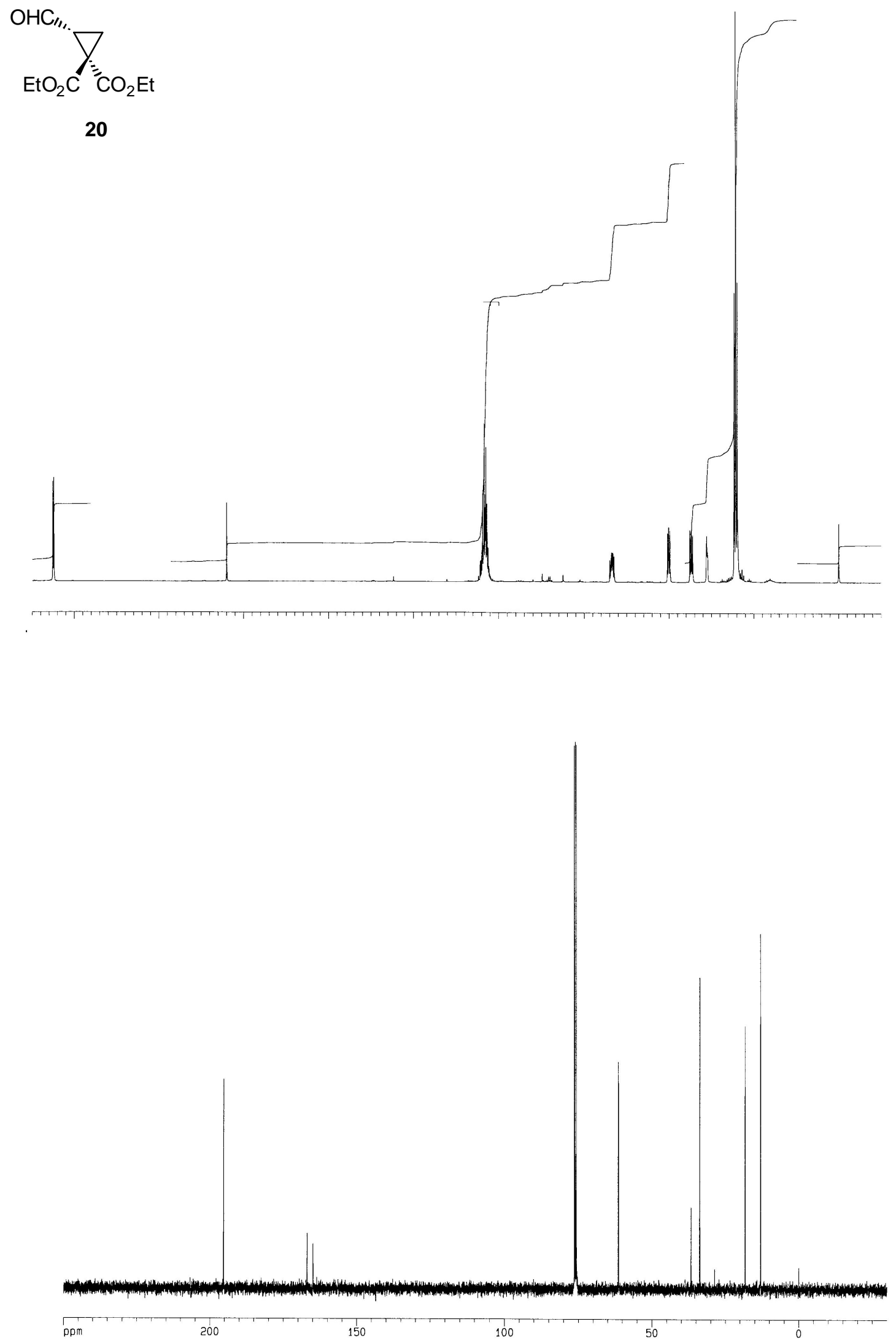

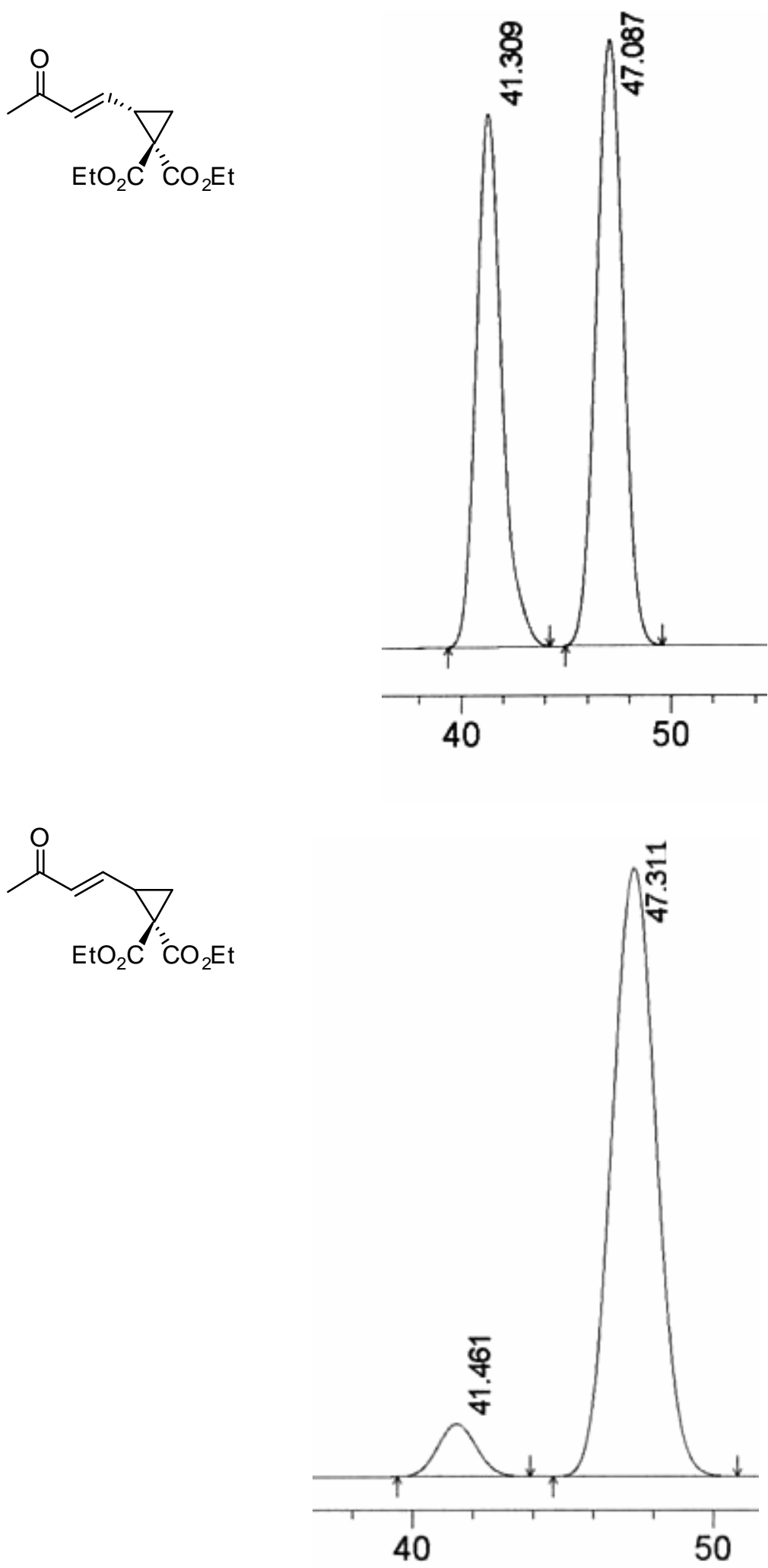